\title{
Edible Flowers: Antioxidant Compounds and Their Functional Properties
}

\author{
Nadhila B. Prabawati ${ }^{1}\left(\mathbb{D}\right.$, Viki Oktavirina $^{1}$, Miguel Palma ${ }^{2}\left(\mathbb{D}\right.$ and Widiastuti Setyaningsih ${ }^{1, *(1)}$ \\ 1 Department of Food and Agricultural Product Technology, Faculty of Agricultural Technology, Gadjah Mada \\ University, Jalan Flora No. 1, Bulaksumur, Sleman, Yogyakarta 55281, Indonesia; \\ nadhilabenita@mail.ugm.ac.id (N.B.P.); viki.o@mail.ugm.ac.id (V.O.) \\ 2 Department of Analytical Chemistry, Faculty of Sciences, IVAGRO, Campus de Excelencia Internacional \\ Agroalimentario (CeiA3), Campus del Rio San Pedro, University of Cadiz, 11510 Puerto Real, Cadiz, Spain; \\ miguel.palma@uca.es \\ * Correspondence: widiastuti.setyaningsih@ugm.ac.id; Tel.: +62-274-549-650
}

Citation: Prabawati, N.B.;

Oktavirina, V.; Palma, M.;

Setyaningsih, W. Edible Flowers:

Antioxidant Compounds and Their

Functional Properties. Horticulturae

2021, 7, 66. https://doi.org/10.3390/

horticulturae7040066

Academic Editors: Silvana Nicola,

Andrea Ertani and Mohammad

Mahdi Jowkar

Received: 25 February 2021

Accepted: 26 March 2021

Published: 1 April 2021

Publisher's Note: MDPI stays neutral with regard to jurisdictional claims in published maps and institutional affiliations.

Copyright: (c) 2021 by the authors. Licensee MDPI, Basel, Switzerland. This article is an open access article distributed under the terms and conditions of the Creative Commons Attribution (CC BY) license (https:// creativecommons.org/licenses/by/ $4.0 /)$.

\begin{abstract}
Edible flowers have been widely consumed for ages until now. The attractive colors and shapes, exotic aroma, and delightful taste make edible flowers very easy to attain. Moreover, they also provide health benefits for consumers due to the unique composition and concentration of antioxidant compounds in the matrices. Knowing the bioactive compounds and their functional properties from edible flowers is necessary to diversify the usage and reach broader consumers. Therefore, this reported review could be useful for functional product development, engaging the discussed edible flowers. We present a comprehensive review of edible flower composition and the functional properties of their antioxidant compounds, mainly phenolics.
\end{abstract}

Keywords: bioactive compounds; phenolics; functional properties; functional food

\section{Introduction}

The existence of edible flowers has attracted attention in various corners of the world. Since ancient Greece and Rome, edible flowers have been widely used in cooking and are still developing up to date [1,2]. On the basis of Scopus, literature about the edible flower was first published in 1934; then, the number increased dramatically in the last decade. This research topic gained significant attention due to the findings of antioxidant compounds and their functional properties, leading to diversifying the utilization of edible flowers for a number of purposes.

Edible flowers can be applied to a variety of needs as food components. Edible flowers can be consumed directly, pre-cooked or merely used as a garnish because their diverse colors are visually appealing. Nowadays, the use of edible flowers for food and beverages appears to be in demand as the population requires a healthy diet to endorse their immunity in face of a global pandemic. In Indonesia, a typical dish from Etlingera elatior (torch ginger) and Sesbania grandiflora (turi) flowers is prepared by boiling the flowers and serving them with peanut sauce. Additionally, Carica papaya and Musa sp flowers are generally consumed as stir-fried vegetables. Several studies reported that roselle (Hibiscus sabdariffa) flowers were used in food product development such as jelly, ready-to-drink beverages, carbonated beverages, fermented products, infusion, sauces, and jams [3,4]. The most practical way to consume roselle flowers is by brewing the stock of simplicia with hot water; this infusion is also commonly accompanied by Clitoria ternatea (butterfly pea) flower. Another bloom with various colors viz., Viola sp. (pansy) is frequently used as garnish for salads, soups, desserts, and beverages [5].

For non-food applications, edible flowers can function as raw materials to produce perfume, natural dye, and cosmetic products. Jasmine flower (Oleaceae family) is predominantly used in the fragrance industry because it contains more than a hundred aromatic 
compounds [6,7], as well as Polianthes tuberosa flower that is also a good source of essential oils [8]. In contrast, pigmented flowers are primarily used for natural dye. The appealing color of torch ginger flowers due to anthocyanin content could be used as a natural dye for lipstick to replace synthetic ones [9], whilst anthocyanins from butterfly pea flowers are utilized as food colorants $[10,11]$. Unlike torch ginger flowers, which give a pink or red extract color, butterfly pea flowers are commonly found in purple or blue petals, even though there are other colors such as red, white, and pink. Apart from their role in fragrance and natural dye industries, edible flowers are essential in food seasoning, i.e., a variety of roses species [12]. Moreover, edible flowers have become an excellent natural food source because of having various bioactive compounds, such as phenolic acids, flavonoids, and other antioxidant compounds that contribute to health benefits $[13,14]$.

The main bioactive compounds, such as phenolic acids and flavonoids in some edible flowers have specific functional properties. Phenolic acids, including chlorogenic acid, gallic acid, $p$-hydroxybenzoic acid, and $p$-coumaric acid, while flavonoid groups, such as flavones, flavonols, flavanones, and anthocyanins are closely related to antioxidant properties $[14,15]$. The antioxidant activities of phenolic compounds are reliable in preventing degenerative diseases such as antidiabetic and cardiovascular disease [16]. Edible flowers with a varied composition of phenolic compounds have also been proven as having antimicrobial, anticancer, and anti-inflammatory effects [17,18]. Besides, phenolic compounds are associated with enzyme inhibitory activity. For example, they have inhibitory activity against $\alpha$-glucosidase and $\alpha$-amylase enzymes, which become potential as an effective hypoglycemic agent $[19,20]$. The phenolics contained by edible flowers also have the capacity to inhibit xanthine oxidase; thus, the uric acid levels in the blood can be controlled [21]. Moreover, phenolic compounds with intense antioxidant activity show neuroprotective effects. Hence, flavonoids can protect the nerve cells of the brain [22].

To take the aforementioned benefits provided by phenolics presented in the edible flowers, there is a growing interest in developing functional foods based on edible flowers for a broader market. Therefore, a comprehensive review of edible flower composition and the functional properties of their compounds will help researchers and food producers design new functional foods. Prior to preparing the review, information related to both ornamental and fruit flowers from subtropical and tropical regions was collected and filtered to select the most appropriate edible flowers to discuss. The data sources were documents published from 2010 to 2020 indexed by Scopus, Google Scholar, ScienceDirect, and Research Gate. The keywords used were edible flower, antioxidant in flower, antiinflammatory in flower, antimicrobial in flower, anticancer in flower, neuroprotective agent in flower, antidiabetic in flower, uricosuric agent in flower, antihemolytic in flower, and edible flowers' functional properties. Document selection had met the exclusion criteria, i.e., the samples used to examine the functional properties of edible flowers were obtained from their essential oil or extracts containing a mixture of flowers (blossoms) with their leaves or stems. Subsequently, a systematic review related to the antioxidant compounds of edible flower and their functional properties, such as antioxidant, anti-inflammatory, antimicrobial, anticancer, neuroprotective, antidiabetic, uricosuric, and antihemolytic, was performed.

\section{The Variant of Edible Flowers}

Edible flowers can be divided into two groups, (i) fruit flowers and (ii) non-fruit flowers (vegetable, medicinal, aromatic, and ornamental flowers), as listed in Table 1 [1,23]. Most of them are not ready-to-eat foods, thus require a particular cooking process before consumption. For example, in Indonesia, fruit flowers such as banana and papaya flowers are priory boiled or sauteed before serving. Meanwhile, non-fruit flowers exist in multiform with more attractive colors, mainly ornamental flowers, and have been widely exploited. Some flowers like roselle, butterfly pea, varieties of roses, and jasmine are consumed as beverages, decorations on salads, and desserts. They improve the quality of food products by their unique taste, color, odor, and various beneficial nutrients [13]. 
Table 1. The variants of edible flowers.

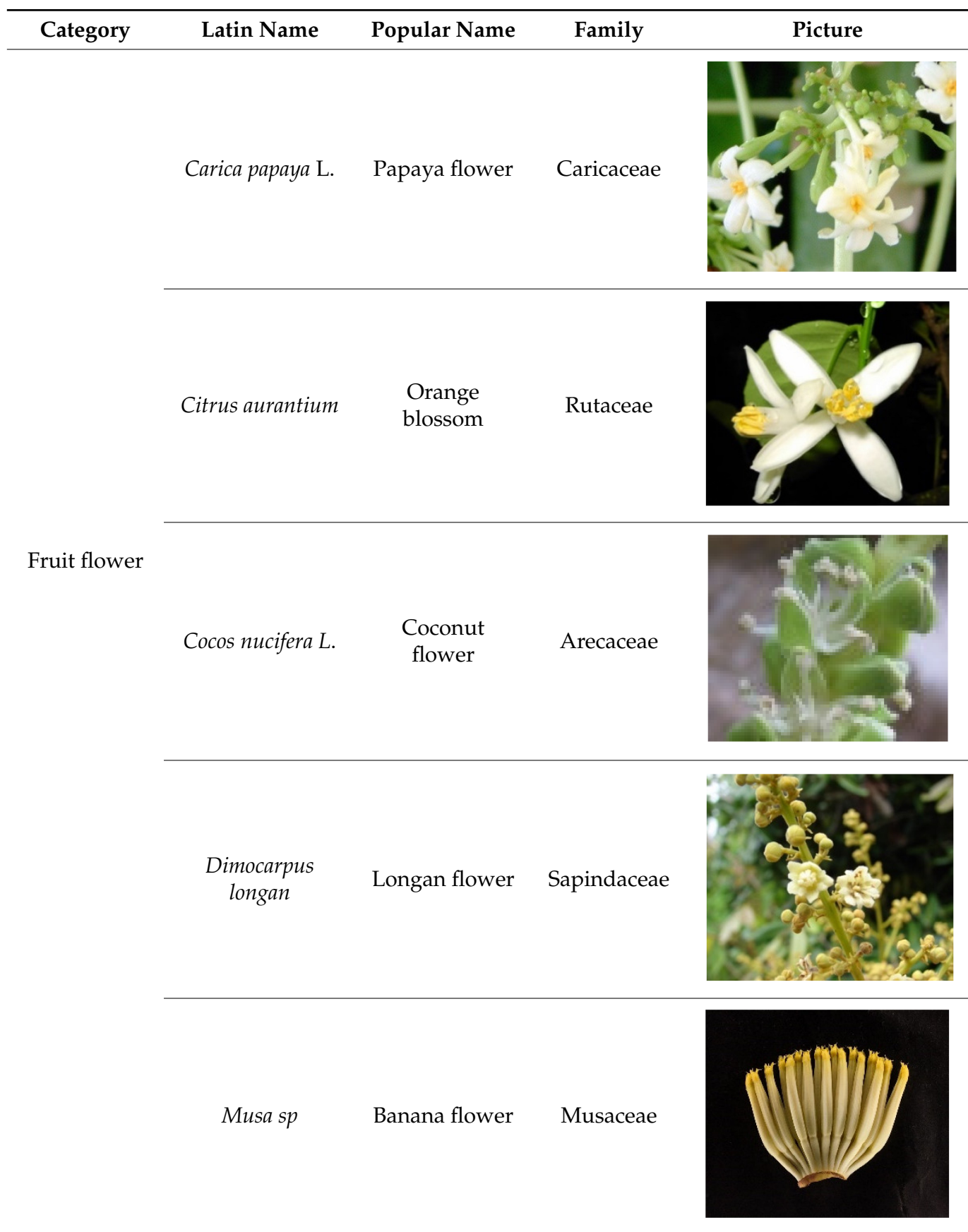


Table 1. Cont.

\begin{tabular}{|c|c|c|c|c|}
\hline Category & Latin Name & Popular Name & Family & Picture \\
\hline \multirow{6}{*}{$\begin{array}{l}\text { Non- } \\
\text { fruit flower }\end{array}$} & $\begin{array}{l}\text { Antirrihinum } \\
\text { majus }\end{array}$ & Snapdragon & Plantaginaceae & \\
\hline & $\begin{array}{c}\text { Brassica oleracea } \\
\text { var. italica }\end{array}$ & Broccoli & Brassicaceae & \\
\hline & $\begin{array}{l}\text { Calendula } \\
\text { officinalis }\end{array}$ & $\begin{array}{c}\text { Marigold, Pot } \\
\text { Marigold, } \\
\text { Calendula }\end{array}$ & Asteraceae & \\
\hline & Clitoria ternatea & Butterfly pea & Fabaceae & \\
\hline & Crocus sativus & Saffron & Iridaceae & \\
\hline & $\begin{array}{l}\text { Cucurbita pepo } \\
\text { var. melopepo }\end{array}$ & Zucchini & Cucurbitaceae & \\
\hline
\end{tabular}


Table 1. Cont.

\begin{tabular}{|c|c|c|c|c|}
\hline Category & Latin Name & Popular Name & Family & Picture \\
\hline & $\begin{array}{c}\text { Cynara } \\
\text { cardunculus } \\
\text { var. scolymus }\end{array}$ & Artichoke & Asteraceae & \\
\hline & Dianthus $s p$ & Carnation & Caryophyllacea & \\
\hline & Etlingera elatior & Torch ginger & Zingiberaceae & \\
\hline & $\begin{array}{c}\text { Geranium } \\
\text { sanguineum }\end{array}$ & Geranium & Geraniaceae & \\
\hline & $\begin{array}{l}\text { Hibiscus } \\
\text { sabdariffa }\end{array}$ & Rosella & Malvaceae & \\
\hline & Ixora coccinea & Ixora & Rubiaceae & \\
\hline
\end{tabular}


Table 1. Cont.

\begin{tabular}{|c|c|c|c|c|}
\hline Category & Latin Name & Popular Name & Family & Picture \\
\hline & $\begin{array}{l}\text { Jasmimum } \\
\text { sambac }\end{array}$ & Jasmine & Jasmineae & \\
\hline & Moringa oleifera & $\begin{array}{c}\text { Moringa, } \\
\text { horseradish }\end{array}$ & Moringaceae & \\
\hline & $\begin{array}{l}\text { Nasturtium } \\
\text { officinale }\end{array}$ & Watercress & Brassicaceae & \\
\hline & $\begin{array}{c}\text { Polianthes } \\
\text { tuberosa }\end{array}$ & $\begin{array}{l}\text { Tuberose, } \\
\text { Agave }\end{array}$ & Asparagaceae & \\
\hline & Rosa & Rose & Rosoideae & \\
\hline & $\begin{array}{c}\text { Sesbania } \\
\text { grandiflora L. }\end{array}$ & $\begin{array}{l}\text { Agathi, } \\
\text { Sesbania }\end{array}$ & Fabaceae & \\
\hline & $\begin{array}{l}\text { Tropaeolum } \\
\text { majus }\end{array}$ & Nasturtium & Tropaeolaceae & \\
\hline
\end{tabular}


Table 1. Cont.

\begin{tabular}{ccccc}
\hline Category & Latin Name & Popular Name & Family & Picture \\
$\begin{array}{c}\text { Viola } x \\
\text { wittrockiana }\end{array}$ & Pansy & Violaceae & & \\
\hline
\end{tabular}

Figure sources: https://www.flower-db.com/ and http://tropical.theferns.info/.

Edible flowers have different characteristics, such as shape, color, brightness, crown thickness, taste, and even nutrient content. In detail, no scientific article has been found regarding the specific differences between fruit and non-fruit flowers. On the contrary, numerous publications focus on the development of new processing technologies [23]. Table 2 shows several types of fruit and ornamental flowers, along with their analytical methods to determine the phytochemical compounds and their functional properties. Apart from containing the major nutrients (protein, carbohydrate, and lipid), edible flowers also contain phenolic acids and flavonoids that provide various functional properties. The details of the functional properties exhibited by edible flowers are reviewed in the next section.

\section{Antioxidant Activity}

Oxidants are chemical species that usually form as free radicals such as hydroxyl $\left(\mathrm{HO}^{*}\right)$, alkoxyl $\left(\mathrm{LO}^{*}\right)$, and reactive oxygen species (ROS) that have unpaired electrons. They are reactive in general and attack other molecules. These chemical species play an essential role in producing energy, synthesizing some essential compounds, and signal transduction. However, they may cause cell damage and lead to some degenerative diseases like cancer, cardiovascular, and neurodegenerative diseases. In an attempt to avoid this cell damage, antioxidants can be applied in scavenging the free radicals. A number of potential sources of natural antioxidants have been identified, including edible flowers.

In flowers, compounds with antioxidant activities are defined as polyphenols, carotenoids, and ascorbic acid [1]. The attractive color of pigment flowers indicates the presence of phenolic acids and flavonoids. It appears in Table 2 that ornamental flowers are containing a higher level of antioxidant compounds than fruit flowers or common horticultural crops [24]. To take advantage of the antioxidant compounds presented in the flowers, some alternatives extraction methods have been developed.

Table 2. Total phenolic content and antioxidant capacity of edible flowers.

\begin{tabular}{|c|c|c|c|c|c|c|}
\hline Edible Flower & Total Phenolics & DPPH & FRAP & ABTS & Health Benefits & Ref. \\
\hline $\begin{array}{c}\text { Bougenville } \\
\text { hybrid }\end{array}$ & $\begin{array}{l}120.7 \mathrm{mg} \\
\mathrm{GAE} / \mathrm{g}\end{array}$ & $\begin{array}{l}\text { L: } 79.62 \% \\
\text { H: } 91.44 \%\end{array}$ & $\begin{array}{l}\text { L: } 58.80 \% \\
\text { H: } 126.6 \%\end{array}$ & N/A & $\begin{array}{l}\text { Analgesic, antidiabetic, } \\
\text { anti-inflammatory, } \\
\text { antimicrobial, } \\
\text { antioxidant, anticancer }\end{array}$ & [25] \\
\hline Brassica oleracea & $0.57 \mathrm{mg}$ GAE $/ \mathrm{g}$ & $2.71 \mu \mathrm{mol} \mathrm{TE} / \mathrm{g}$ & $\mathrm{N} / \mathrm{A}$ & $\mathrm{N} / \mathrm{A}$ & Antioxidant, anticancer & [26] \\
\hline $\begin{array}{c}\text { Brassica oleraea } \\
\text { var. italica }\end{array}$ & $\begin{array}{l}10.27 \mathrm{mg} \\
\mathrm{GAE} / \mathrm{g}\end{array}$ & $3.85 \mu \mathrm{mol} \mathrm{TE} / \mathrm{g}$ & $\mathrm{N} / \mathrm{A}$ & $\mathrm{N} / \mathrm{A}$ & Antioxidant, anticancer & {$[26,27]$} \\
\hline $\begin{array}{l}\text { Calendula } \\
\text { arvensis }\end{array}$ & $\begin{array}{c}50.26 \mathrm{mg} \\
\mathrm{GAE} / \mathrm{g}\end{array}$ & $\begin{array}{c}20.9 \mathrm{IC}_{50} \\
\mu \mathrm{g} / \mathrm{mL}\end{array}$ & $\begin{array}{c}203.96 \mathrm{mg} \\
\mathrm{AAE} / \mathrm{g}\end{array}$ & N/A & $\begin{array}{c}\text { Antioxidant, } \\
\text { antimicrobial, } \\
\text { anticancer }\end{array}$ & [28] \\
\hline
\end{tabular}


Table 2. Cont.

\begin{tabular}{|c|c|c|c|c|c|c|}
\hline Edible Flower & Total Phenolics & DPPH & FRAP & ABTS & Health Benefits & Ref. \\
\hline $\begin{array}{l}\text { Calendula } \\
\text { officinalis }\end{array}$ & $\begin{array}{l}34.27 \mathrm{mg} \\
\mathrm{GAE} / \mathrm{g}\end{array}$ & $34.75 \mathrm{mg}$ TE/g & $58.96 \mathrm{mg} \mathrm{TE} / \mathrm{g}$ & $48.15 \mathrm{mg} \mathrm{TE} / \mathrm{g}$ & $\begin{array}{c}\text { Antioxidant, } \\
\text { anti-inflammatory, } \\
\text { antimicrobial }\end{array}$ & [29] \\
\hline Carica papaya & 0.76 mg GAE/g & $64.07 \%$ & $\mathrm{~N} / \mathrm{A}$ & $\mathrm{N} / \mathrm{A}$ & $\begin{array}{l}\text { Antioxidant, } \\
\text { antibacterial }\end{array}$ & [30] \\
\hline $\begin{array}{c}\text { Citrus } \\
\text { aurantium }\end{array}$ & $\begin{array}{l}87.96 \mathrm{mg} \\
\mathrm{GAE} / \mathrm{g}\end{array}$ & $\begin{array}{c}87.15 \mathrm{IC}_{50} \\
\mu \mathrm{g} / \mathrm{mL}\end{array}$ & $\mathrm{N} / \mathrm{A}$ & $\mathrm{N} / \mathrm{A}$ & $\begin{array}{l}\text { Antioxidant, } \\
\text { antimicrobial, } \\
\text { neuroprotective }\end{array}$ & [31] \\
\hline Clitoria ternatea & $\begin{array}{l}76.90 \mathrm{mg} \\
\mathrm{GAE} / \mathrm{g}\end{array}$ & $\begin{array}{c}0.76 \mathrm{IC}_{50} \\
\mu \mathrm{g} / \mathrm{mL}\end{array}$ & $10.91 \mathrm{mM} \mathrm{TE} / \mathrm{g}$ & $4.16 \mathrm{mM} \mathrm{TE} / \mathrm{g}$ & $\begin{array}{l}\text { Antioxidant, } \\
\text { anticancer, } \\
\text { neuroprotective }\end{array}$ & [32] \\
\hline Cocos nucifera & $\begin{array}{l}222.61 \mathrm{mg} \\
\mathrm{GAE} / \mathrm{g}\end{array}$ & $\begin{array}{c}40.5 \mathrm{IC}_{50} \\
\mu \mathrm{g} / \mathrm{mL}\end{array}$ & $\begin{array}{c}89.84 \mathrm{IC}_{50} \\
\mu \mathrm{g} / \mathrm{mL}\end{array}$ & $\begin{array}{c}66.94 \mathrm{IC}_{50} \\
\mu \mathrm{g} / \mathrm{mL}\end{array}$ & $\begin{array}{c}\text { Antioxidant, } \\
\text { antidiabetic, } \\
\text { cytoprotective, } \\
\text { hepatoprotective }\end{array}$ & {$[33,34]$} \\
\hline $\begin{array}{c}\text { Dianthus } \\
\text { carmelitarum }\end{array}$ & 12.6 mg GAE/g & $\begin{array}{c}1.22 \mathrm{IC}_{50} \\
\mu \mathrm{g} / \mathrm{mL}\end{array}$ & 238 mM TE/g & $\mathrm{N} / \mathrm{A}$ & $\begin{array}{l}\text { Antioxidant, } \\
\text { antigenotoxic, } \\
\text { antimicrobial, } \\
\text { anticancer }\end{array}$ & [35] \\
\hline $\begin{array}{l}\text { Dimocarpus } \\
\text { longan Lour. }\end{array}$ & $\begin{array}{l}476.8 \mathrm{mg} \\
\mathrm{GAE} / \mathrm{g}\end{array}$ & $\begin{array}{c}3.81 \mathrm{IC}_{50} \\
\mu \mathrm{g} / \mathrm{mL}\end{array}$ & $\mathrm{N} / \mathrm{A}$ & $8.8 \mathrm{mM} \mathrm{TE} / \mathrm{g}$ & $\begin{array}{c}\text { Antioxidant, } \\
\text { antiinflammatory, } \\
\text { antidiabetic }\end{array}$ & {$[36,37]$} \\
\hline Etlingera elatior & 4.85 mg GAE/g & $\begin{array}{l}9.52 \mathrm{IC}_{50} \\
\mu \mathrm{g} / \mathrm{mL}\end{array}$ & $\begin{array}{c}19.43 \mathrm{mmol} \\
\mathrm{FE} / \mathrm{g}\end{array}$ & $\mathrm{N} / \mathrm{A}$ & $\begin{array}{l}\text { Antioxidant, } \\
\text { antimicrobial, } \\
\text { neuroprotective }\end{array}$ & [38] \\
\hline $\begin{array}{l}\text { Hibiscus } \\
\text { sabdariffa }\end{array}$ & 29.2 mg GAE/g & $78 \%$ & $2.31 \mathrm{mM} \mathrm{TE} / \mathrm{g}$ & $7.8 \mathrm{mM} \mathrm{TE} / \mathrm{g}$ & $\begin{array}{l}\text { Anti-inflammatory, } \\
\text { antioxidant, anticancer }\end{array}$ & [39-41] \\
\hline Moringa oleifera & $\begin{array}{l}19.31 \mathrm{mg} \\
\mathrm{GAE} / \mathrm{g}\end{array}$ & $\begin{array}{l}\text { 14.57 IC50 } \\
\mu \mathrm{g} / \mathrm{mL}\end{array}$ & $\mathrm{N} / \mathrm{A}$ & $\mathrm{N} / \mathrm{A}$ & $\begin{array}{c}\text { Antioxidant, } \\
\text { anti-inflammatory }\end{array}$ & [42] \\
\hline Musa $A B B$ & $9.44 \mathrm{mg} \mathrm{GAE} / \mathrm{g}$ & $\begin{array}{l}27.96 \mu \mathrm{mol} \\
\mathrm{TE} / \mathrm{g}\end{array}$ & $20.6 \mu \mathrm{mol} \mathrm{TE} / \mathrm{g}$ & $\begin{array}{c}30.66 \mu \mathrm{mol} \\
\mathrm{TE} / \mathrm{g}\end{array}$ & $\begin{array}{c}\text { Antioxidant, } \\
\text { antidiabetic, DF rich } \\
\text { source, neuroprotective }\end{array}$ & [43] \\
\hline $\begin{array}{l}\text { Musa sp. vVar. } \\
\text { elakki bale }\end{array}$ & $\begin{array}{l}121.8 \mathrm{mg} \\
\mathrm{GAE} / \mathrm{g}\end{array}$ & $\begin{array}{c}9.35 \mathrm{IC}_{50} \\
\mu \mathrm{g} / \mathrm{mL}\end{array}$ & $\begin{array}{c}39.03 \mathrm{mM} \\
\mathrm{AA} / \mathrm{g}\end{array}$ & $\mathrm{N} / \mathrm{A}$ & $\begin{array}{l}\text { Antidiabetic, } \\
\text { anti-AGEs, } \\
\text { antimicrobial }\end{array}$ & {$[44,45]$} \\
\hline $\begin{array}{l}\text { Nasturtium } \\
\text { officinale }\end{array}$ & 1.44 mg GAE/g & $7.76 \mu \mathrm{mol} \mathrm{TE} / \mathrm{g}$ & $\mathrm{N} / \mathrm{A}$ & $\mathrm{N} / \mathrm{A}$ & Antioxidant, anticancer & [26] \\
\hline $\begin{array}{c}\text { Rosa damascena } \\
\text { Mill }\end{array}$ & $\begin{array}{l}233.56 \mathrm{mg} \\
\mathrm{GAE} / \mathrm{g}\end{array}$ & $74.03 \%$ & $0.64 \mu \mathrm{g} / \mathrm{mL}$ & $\mathrm{N} / \mathrm{A}$ & Antioxidant & [46] \\
\hline Tagetes erecta & $28.9 \mathrm{mg} \mathrm{GAE} / \mathrm{g}$ & $\begin{array}{l}\text { L: } 85.70 \% \\
\text { H: } 94 \%\end{array}$ & $\begin{array}{l}\text { L: } 60.92 \% \\
\text { H: } 203.8 \%\end{array}$ & $\mathrm{~N} / \mathrm{A}$ & $\begin{array}{l}\text { Anti-inflammation, } \\
\text { neuroprotective }\end{array}$ & [25] \\
\hline $\begin{array}{l}\text { Tropaeolum } \\
\text { majus }\end{array}$ & $\begin{array}{l}12.95 \mathrm{mg} \\
\mathrm{GAE} / \mathrm{g}\end{array}$ & $\mathrm{N} / \mathrm{A}$ & $\mathrm{N} / \mathrm{A}$ & $9.51 \mu \mathrm{mol} \mathrm{TE} / \mathrm{g}$ & Antioxidant & [47] \\
\hline $\begin{array}{c}\text { Viola } \\
\text { wittrockiana }\end{array}$ & $\begin{array}{l}44.88 \mathrm{mg} \\
\mathrm{GAE} / \mathrm{g}\end{array}$ & $\begin{array}{l}26.1 \mathrm{IC}_{50} \\
\mu \mathrm{g} / \mathrm{mL}\end{array}$ & $35 \mathrm{mmol} \mathrm{Fe} / \mathrm{g}$ & $\mathrm{N} / \mathrm{A}$ & $\begin{array}{l}\text { Neuroprotective, } \\
\text { antioxidant }\end{array}$ & {$[48,49]$} \\
\hline
\end{tabular}

GAE: gallic acid equivalent; L: lowest value detected; $\mathrm{H}$ : highest value detected; N/A: not available; TE: trolox equivalent; \%: \% inhibition; IC50: half maximal inhibitory concentration.

Diverse procedures have been proposed to extract antioxidant compounds from edible flowers with different settings of extraction factors, including solvent, time, temperature, and solid-to-solvent ratio. The polar solvents, such as methanol, ethanol, and water have been widely used to extract antioxidant compounds from edible flowers. These solvents are selected for extraction due to the high polarity of phenolic compounds [2]. Additionally, the extractions are commonly taken place at an ambient temperature [50], while some experiments require a higher temperature ( 35 to $100^{\circ} \mathrm{C}$ ). The main reason for applying a higher temperature is to reduce the extraction time as the higher the temperature, the shorter the extraction time, and vice versa. Soxhlet is the most frequent extraction 
method with high temperature, while maceration can be performed in a wide range of operating temperatures [51]. Different extraction procedures could produce varied levels of antioxidant compounds of the resulting extract.

The level of antioxidant compounds is commonly presented as total phenolic contents. However, other antioxidant parameters are evaluated by assays, indicating the antioxidant capacity of edible flowers, such as DPPH (2,2-diphenyl-1-picrylhydrazyl), FRAP (ferric reducing antioxidant power), and ORAC (oxygen radical absorbance capacity) [24]. DPPH is a method for assessing free radical scavenging activity, ferric reducing antioxidant power (FRAP) assesses the ability to reduce free radicals, while ABTS estimates single electron transfer capabilities [52]. Former studies reported that phenolics are the main compounds contributing the antioxidant capacity. Hence, provided that an edible flower has a diverse and greater amount of phenolic compounds, the flower may exhibit high antioxidant activity $[53,54]$. As a reference, the total phenolic content and antioxidant capacity of some edible flowers assessed by several methods are listed in Table 2 .

Table 2 shows the diversity of total phenolic content and antioxidant activity in edible flowers. It is not easy to compare the results of the antioxidant assays nor the reducing activities because different assays are using different reference compounds. Therefore, the results are expressed in different ways in the literature. From these data, it is also challenging to know the differences between a fruit flower or an ornamental flower. Likewise, flowers with intense colors and soft ones. For example, Musa sp. Var. Elakki bale and Citrus aurantium as fruit flower had phenolic content 121.8 and $87.96 \mathrm{mg} \mathrm{GAE} / \mathrm{g}$, respectively. While Bougenville hybrid and Clitoria ternatea as non-fruit flower had phenolic content 120.7 and $76.9 \mathrm{mg} \mathrm{GAE} / \mathrm{g}$. However, flowers with intense color appear to have high total phenolic content such as Calendula arvensis, Viola wittrockiana, Hibiscus sabdariffa, and Tagetes erecta at 50.26, 44.88, 29.2, $28.9 \mathrm{mg} \mathrm{GAE} / \mathrm{g}$, respectively. Apart from different tests, the authors suspect these differences are also due to differences in the age of the flowers. Because, during senescence, plants will experience biochemical changes and the formation of ROS, which indeed results in a decrease in antioxidant activity [55]. However, this still requires further research.

Phenolic compounds are plant derivative compounds easily found in several vegetables and fruits and also consumed in the daily food intake. For example, kale, cucumber, and celery have total phenolic content (TPC) of $36.89 \mathrm{mg} / \mathrm{g}, 14.37 \mathrm{mg} / \mathrm{g}$, and $14.95 \mathrm{mg} / \mathrm{g}$, respectively [56,57]. The phenolic content in vegetables is still lower when compared to the phenolic content in edible flowers. The same thing happens in fruit. Mulberry fruit (Morus atropurpurea Roxb.) only contains a TPC value of $11.33 \mathrm{mg} / \mathrm{g}$ [58]. Moreover, its antioxidant activity is lower than edible flowers. The result of ABTS and DPPH assays were 4.11 and $10.08 \mu \mathrm{g} \mathrm{TE} / \mathrm{mL}$, respectively [58]. Still, there is a wide range of antioxidant levels for edible flowers, fruits, and vegetables. From this study, it can be seen that each type of food matrices has a different antioxidant activity, which is influenced by its antioxidant components.

\section{Anti-Inflammatory}

Inflammation is a physiological response from a host in protecting themselves from toxins and pathogens [59] in the form of infections, chemical exposure, tissue damage, and exposure to bacterial components such as lipopolysaccharide (LPS) [60,61]. Some macrophages, including inflammatory cytokines, such as tumor necrosis factor- $\alpha$ (TNF- $\alpha$ ) and interleukin-1 $\beta$ [62], and inflammatory mediators, such as a nitric oxide (NO) and prostaglandin E2 (PGE2), which is synthesized by inducible NO synthase (iNOS) and cyclooxygenase-2 (COX-2) [63], if overproduced, can endanger tissues and organisms. Consequences are various inflammation-related diseases, such as rheumatoid arthritis, diabetes, inflammatory bowel disease, atherosclerosis, and cancer [64].

Several studies have shown that flavonoids, anthocyanins, and phenolic acids are active components that are responsible for anti-inflammatory properties, as listed in Table 3 [65]. For example, in the LPS-induced RAW 264.7 system model, anthocyanins 
from Hibiscus (delphinidin 3-sambubioside) can reduce some LPS-induced inflammatory mediators, such as iNOS/NO, interleukin-6 (IL-6), monocyte chemoattractant protein-1 (MCP-1), and TNF- $\alpha$ [66]. In addition, phenolic compounds called ellagic acid from Rosa rugosa Thunb flower extract can reduce the production of inflammatory mediators such as NO, PGE2, and inflammatory cytokines such as TNF- $\alpha$, IL-6, and IL-1 $\beta$ [67]. Other flowers such as Butea monosperma and Ginkgo biloba L. are also known to inhibit the formation of those inflammatory mediators and cytokines $[68,69]$.

Table 3. Anti-inflammatory activities in edible flowers.

\begin{tabular}{|c|c|c|c|c|}
\hline Edible Flower & Compounds & Assessment & Activities & Ref. \\
\hline $\begin{array}{c}\text { Butea } \\
\text { monosperma } \\
\text { (Lam.) Taubert }\end{array}$ & Butrin, isobutrin & In vivo & $\begin{array}{l}\text { Suppressed IL-1 } \beta, \text { IL-6, } \\
\text { IL8, PGE2 }\end{array}$ & {$[68]$} \\
\hline Ginkgo biloba L. & Bilobetin, isoginkgetin & In vivo & $\begin{array}{c}\text { Suppressed NO, TNF- } \alpha \text {, } \\
\text { IL-6, PGE2, iNOS, } \\
\text { COX-2 }\end{array}$ & [69] \\
\hline $\begin{array}{l}\text { Hibiscus } \\
\text { sabdariffa } \mathrm{L}\end{array}$ & $\begin{array}{l}\text { Delphinidin } \\
\text { 3-sambubioside, } \\
\text { delphinidin }\end{array}$ & In vitro, In vivo & $\begin{array}{c}\text { Suppressed iNOS, NO, } \\
\text { IL-6, MCP-1, TNF- } \alpha\end{array}$ & {$[66]$} \\
\hline Moringa oleifera & Tannins (not specific) & In vitro & $\begin{array}{l}\text { Inhibited protein } \\
\text { denaturation in } \\
58 \%-101 \%\end{array}$ & [42] \\
\hline $\begin{array}{c}\text { Rosa rugosa } \\
\text { Thunb }\end{array}$ & Ellagic acid & In vivo & $\begin{array}{l}\text { Suppressed NO, PGE2, } \\
\text { TNF- } \alpha, \text { IL-6, IL-1 } \beta, \\
\text { iNOS, COX-2 }\end{array}$ & [67] \\
\hline $\begin{array}{c}\text { Sesbania } \\
\text { grandiflora L. } \\
\text { Fabaceae }\end{array}$ & $\begin{array}{l}\text { Flavonoids (not } \\
\text { specific) }\end{array}$ & In vivo & $\begin{array}{l}\text { Inhibited edema } \\
\text { formation up to } 79 \% \text { in } \\
5 \mathrm{~h}\end{array}$ & {$[70]$} \\
\hline
\end{tabular}

Another anti-inflammatory activity was also found in M. oleifera flower extract because it prevented protein denaturation and was comparable to standard drug sodium diclofenac [42]. Flavonoids from Sesbania grandiflora L. Fabaceae also inhibited edema formation which closely related to inflammation [70]. However, further research is needed to find out which components are really responsible for anti-inflammatory activity and its mechanisms.

\section{Antimicrobial}

Antimicrobial activity in edible flowers depends on the presence of certain microorganism inhibiting compounds. Commonly, those compounds are from the phenolic group. Several antimicrobial activities in edible flowers are listed in Table 4. Phenolic extracts from Sesbania grandiflora flower, especially those containing rutin, have inhibitory activity against Staphylococcus aureus, Shigella flexneri, Salmonella Typhi, Escherichia coli, and Vibrio cholera [71]. Extracts from Rosa rugosa flower containing gallic acid also exhibit antimicrobial activity against Staphylococcus epidermis, S. aureus, Bacillus subtilis, M. luteus, Escherichia coli, Klebsiella pneumoniae, Pseudomonas aeruginosa, Proteus mirabilis [72]. Quinic acid from Citrus aurantium L. flower extract also had antimicrobial activity against Escherichia coli Pseudomonas aeruginosa, Staphylococcus aureus, and Bacillus cereus [73]. Etlingera elatior and Hibiscus sabdariffa flower also have the inhibition to several pathogen bacteria. Not only phenolic compounds but also proteins can exhibit antimicrobial activity. Musa sapientum L. flower contains amino acids called tyrosine and tryptophan that exhibit antimicrobial activity against $S$. aureus and E. coli [74]. Based on those facts, it is very possible for edible flowers to become a source of antimicrobial compounds for both the human body and food which functions to keep food from spoiling quickly. 
Table 4. Antimicrobial activities in edible flowers.

\begin{tabular}{|c|c|c|c|c|}
\hline Edible Flower & Compounds & Method & Microorganisms & Ref. \\
\hline Citrus aurantium L. & Quinic acid & Agar well-diffusion & E. coli, $P$. aeruginosa, S. aureus, B. cereus & [73] \\
\hline Etlingera elatior & $\begin{array}{l}\text { Gallic acid, caffeic acid, } \\
\text { tannic acid }\end{array}$ & Agar well-diffusion & $\begin{array}{l}\text { S. aureus, B. subtilis, L. monocytogenes, } \\
\text { E. coli, S. typhimurium, P. aeruginosa }\end{array}$ & [18] \\
\hline Hibiscus sabdariffa L. & Phenolics (not specific) & Agar cup diffusion & $\begin{array}{c}\text { Inhibited E. coli, S. aureus, Str. Mutans, } \\
\text { P. aeruginosa }\end{array}$ & [75] \\
\hline Rosa rugosa & Gallic acid & Micro-broth dilution & $\begin{array}{l}\text { S. epidermidis, S. aureus, B. subtilis, } M . \\
\text { luteus, E. coli, K. pneumoniae, } P . \\
\text { aeruginosa, Proteus mirabilis) }\end{array}$ & [72] \\
\hline Sesbania grandiflora & Rutin & Agar well-diffusion & $\begin{array}{l}\text { S. aureus, S. flexneri, S. typhi, E. coli, } \\
\text { Vibrio cholera }\end{array}$ & [71] \\
\hline
\end{tabular}

\section{Anticancer}

Cancer is a kind of malignant tumor caused by abnormal cell growth. These cells will develop and spread to other body tissues, referred to as metastasis [76]. Cancer is classified as a deadly disease, and this fact is proven by the high number of new cases and mortality [77]. For example, globally, breast cancer is the most dangerous type of cancer for women. Approximately 1.1 million deaths were reported in 2018. This number is lower than deaths from lung cancer $[78,79]$.

Reactive oxygen species (ROS) is claimed as one of the causes of the development of the cancer phase [80] and involved in tumor cell metastases [81]. According to [70], an approach with antioxidants can reduce cell injury or inflammation caused by ROS, including superoxide $\left(\mathrm{O}^{2-}\right)$, hydroxyl radical $(\mathrm{OH})$, and $\mathrm{H}_{2} \mathrm{O}_{2}$. Therefore, antioxidants have a major effect as antimetastatic and chemopreventive [81].

Recent studies reveal the relationship between antioxidant activity and cancer inhibitory [82]. Antioxidant compounds, including polyphenols, phenolic acids, flavonoids, and their derivatives, have an important role in disrupting the development of cancer cells $[80,83]$, vis., initiation, promotion, and progression stages and also polyphenols are referred to as anti-carcinogenic agents [84]. The most common approach to cancer treatment is chemotherapy. This therapy relies on the ability of strong chemical medicine to destroy, slow down, and even stop the growth of cancer cells. However, this treatment provides side effects for patients, so the use of natural medicine is proposed as an alternative treatment [76].

Natural or herbal medicine is an alternative treatment that uses natural ingredients such as plants, including edible flowers. Several studies revealed that bioactive compounds such as phenolic and flavonoids from edible flowers have anticancer activity. In addition, previous studies reported that phenolic compounds from edible flowers have preventive and healing properties [17]. Polyphenols from plants have strong antioxidant activity and can provide a protective effect, especially against DNA damage (oxidative damage). Oxidative damage is the beginning of cancer development or also known as a crucial stage. Some common phenolics such as chlorogenic acid, quercetin, gallic acid, caffeic acid, and tannic acid are against cancer activity $[18,61,63]$.

In Table 5, we have listed several edible flowers that have been shown to inhibit some cancer cells. MTT (dimethylthiazol-diphenyltetrazolium bromide) colometric assay and SRB (sulforhodamine B) assay were used. MTT assay determines cell viability, while SRB assay is a test for chemosensitivity [85]. Based on in vitro tests using MTT and SRB assays, these flowers have the ability to inhibit the growth of breast, cervical, hepatocellular, lung, and colon cancer cell line. However, there is still very limited research that shows how long the dose of edible flower should be given to patients with cancer until the cancer cells are completely removed from the body. 
Table 5. Anticancer activities in edible flowers.

\begin{tabular}{|c|c|c|c|c|}
\hline Edible Flower & Compounds & Assessment & Cancer Lines & Ref. \\
\hline Calendula officinalis & $\begin{array}{l}\text { Chlorogenic acid, } \\
\text { quercetin, isorhamnetin }\end{array}$ & In vitro (MTT assay) & $\begin{array}{c}\text { Breast cancer cell line (MCF-7, } \\
\text { MDA-MB-231, Hs578T) }\end{array}$ & {$[86]$} \\
\hline Carica papaya & $\begin{array}{c}\text { Stigmast-4-ene-3-one, } \\
\text { benzyl } \\
\beta \text {-D-glucopyranoside, } \\
\text { uracil }\end{array}$ & In vitro (SRB assay) & $\begin{array}{l}\text { Breast cancer cell line (MCF-7), } \\
\text { cervical cancer (HeLa), hepatocellular } \\
\text { (Hep-G2), lung carcinoma (NCI-H460) }\end{array}$ & [87] \\
\hline Etlingera elatior & $\begin{array}{c}\text { Gallic acid, caffeic acid, } \\
\text { tannic acid }\end{array}$ & In vitro (MTT assay) & $\begin{array}{l}\text { Human breast carcinoma cell lines } \\
\text { (MCF-7 and MDA-MB-231), } \\
\text { hepatocellular carcinoma (HepG2), } \\
\text { colon carcinoma (HT-29), cervical } \\
\text { cancer (HeLa) }\end{array}$ & {$[18,88]$} \\
\hline Musa paradisiaca & Phenolics (not specific) & In vitro (MTT assay) & Cervical cancer cell line (HeLa) & [89] \\
\hline $\begin{array}{c}\text { Sesbania grandiflora L. } \\
\text { Fabaceae }\end{array}$ & $\begin{array}{l}\text { Flavonoids (not } \\
\text { specific) }\end{array}$ & In vitro (MTT assay) & Human cancer cell line (HeLa) & [70] \\
\hline
\end{tabular}

\section{Neuroprotective Agent}

Neurodegenerative disorders (ND) are a progressive loss of central nervous system (CNS) or neuron dysfunction such as Alzheimer's, Parkinson's, and Huntington's diseases caused by cell degeneration and even cell death [90,91]. This neuron degeneration is a polyfactorial or multifactorial genetic disease that involves a combination of genetic (e.g., genetic mutase) and non-genetic or environmental factors such as oxidative stress, inflammation, neuronal apoptosis, etc. [90,92].

Alzheimer's disease (AD) is a brain disorder that results in decreased memory, cognitive decline, and behavior change gradually. This condition is more commonly occur in people over 65 years old. The initial stage of this disease affects the ability of memory, while sensory and motor functions are still normal. Whilst Parkinson's disease (PD) is a neurological disease that affects movement coordination. As a result, sufferers have difficulty regulating body movements such as walking, regulating balance, rigidity, tremor, and bradykinesia (slowness of movement) [93].

Reduction of acetylcholine (ACh) levels in presynaptic is a symptom of cognitive impairment in AD's sufferers. Acetylcholine is a neurotransmitter that sends signals from one nerve cell to the target. The increase in acetylcholine can be done by inhibiting the activity of the enzyme cholinesterase or acetylcholinesterase (AChE) and butyrylcholinesterase $(\mathrm{BuChE})$ in hydrolyzing acetylcholine $[17,94]$. While ROS is claimed to be involved in the selective degeneration of dopaminergic neurons in PD sufferers. This mechanism occurs in the metabolism of dopamine (as a neurotransmitter), which produces free radicals that cause oxidative stress [93].

Neuroprotective agents are needed as an approach in protecting neuron damage to the CNS. Parts of medicinal plants such as leaves, flowers, fruits, and seeds are reported to be used as alternative therapies [93]. Edible flowers are high in phenolic compounds that can act as a neuroprotective agent. Phenolics such as flavonoids provide the effect of increasing the function or regeneration of nerve cells, avoiding the formation of ROS, and reducing the oxidation of proteins. Furthermore, flavonoids have various benefits in protecting the nerves of the brain, including minimizing nerve inflammation and nerve injury caused by neurotoxins, as well as improving cognitive function and memory [22,92]. Non-flavonoid phenolics such as phenolic acids also have a similar ability [17].

From Table 6, it can be seen that some of the neuroprotective mechanisms of edible flowers are inhibiting the performance of the enzymes. Phenolic acid, such as syringic acid, salicylic acid, chlorogenic acid from Butea monosperma and Sesbania grandiflora inhibit the enzymes $\mathrm{AChE}$ and $\mathrm{BuChE}$ which leads to prevent the breakdown of acetylcholine, so that the acetylcholine content in the nerves does not decrease [17]. Viola wittrockiana flower is also known to inhibit AChE and monoamine oxidase A [49]. This inhibitory activity may be due to the high content of quercetin and other flavonoids such as anthocyanin. Quercetin 
also inhibits the secretase enzyme in producing Amyloid- $\beta(A \beta)[95,96]$. A $\beta$ is a peptide that has been associated with Alzheimer's due to the accumulation of amyloid plaque. Another mechanism was also found in Crocus sativus L. Based on in vivo test results, the content of crocins can reduce extracellular ATP in the retina, so that retinal nerve damage can be avoided (Maggi2020).

Table 6. Neuroprotective activities in edible flowers.

\begin{tabular}{|c|c|c|c|c|}
\hline Edible Flower & Compounds & Assessment & Activities & Ref. \\
\hline $\begin{array}{l}\text { Butea monosperma } \\
\text { (Lam.) Taub. }\end{array}$ & Syringic and salicylic acid & $\begin{array}{c}\text { In vitro enzyme } \\
\text { inhibitory }\end{array}$ & Inhibited $\mathrm{AChE}$ and $\mathrm{BuChE}$ & {$[17]$} \\
\hline Crocus sativus L. & Crocins & $\begin{array}{l}\text { In vivo (morphological } \\
\text { evaluation by } \\
\text { quantitative histology) }\end{array}$ & $\begin{array}{l}\text { Protect retinal neurons from } \\
\text { light damage }\end{array}$ & [97] \\
\hline Sesbania grandiflora L. & $\begin{array}{l}\text { Chlorogenic acid, } \\
\text { neochlorogenic acids and } \\
\text { catechin hydrate }\end{array}$ & $\begin{array}{l}\text { In vitro enzyme } \\
\text { inhibitory }\end{array}$ & Inhibited AChE and BuChE & [17] \\
\hline Viola $x$ wittrockiana & $\begin{array}{l}\text { quercetin-3-O-(6-O- } \\
\text { rhamnosylglucoside)-7-O- } \\
\text { rhamnoside }\end{array}$ & $\begin{array}{l}\text { In vitro enzyme } \\
\text { inhibitory }\end{array}$ & $\begin{array}{l}\text { Inhibited AChE and } \\
\text { monoamine oxidase A }\end{array}$ & [49] \\
\hline
\end{tabular}

In addition, when compared with other matrices such as fruit, flowers such as marigold (Tagetes erecta) [61] and E. elatior [18] showed higher chlorogenic acid content when compared to Mulberries fruit extract $(0.136-0.517 \mathrm{mg} / \mathrm{g}$ ) [33]. This information indicates the high potential of edible flowers to be a neuroprotective agent. However, more data are needed to draw this conclusion.

\section{Antidiabetic}

Diabetes mellitus (DM) is a non-communicable disease characterized by an abnormally elevated blood glucose level. This condition due to pancreatic beta cells damage so that insulin production has decreased or not fulfilled, called type I diabetes mellitus (T1DM). Meanwhile, type II diabetes mellitus (T2DM) is normal insulin production but the body is less sensitive, also called insulin resistance [98,99].

Insulin is a hormone produced by pancreatic beta cells. This hormone functions to control blood sugar by converting glucose into energy and spread throughout the body or stored in the form of glycogen. Failure of insulin production can cause an accumulation of glucose in the blood, also called hyperglycemia. Insulin therapy is used as a general approach for people with type I diabetes. While T2DM is non-insulin-dependent [20]. Furthermore, other therapeutic approaches that can be taken are by inhibiting the action of the $\alpha$-glucosidase and $\alpha$-amylase enzymes because $\alpha$-amylase is a starch hydrolyzing enzyme, while $\alpha$-glucosidase plays a role in the absorption of glucose in the small intestine. The purpose of the inhibition of digestive enzymes is to suppress the increase in blood glucose by delaying the digestion of carbohydrates [20,100]. Then, besides maintaining blood sugar, the most important goal of diabetes treatment is to prevent or delay complications, such as microvascular complications, including damage to the eye (retinopathy), kidney dysfunction (nephropathy), nerves dysfunction (neuropathy), diabetic angiopathy (narrowing of the blood vessels), and macrovascular complications, including cardiovascular disease [101,102].

Acarbose [99] and metformin are antidiabetic drugs that are widely consumed by people with type 2 diabetes. This drug is quite expensive and has undesirable side effects [103]. At present, natural products are being highlighted as an alternative treatment for managing diabetes. Medicinal plants have the potential as safe and effective hypoglycemic agents (lowering blood sugar level). This effect is associated with the presence of natural bioactive compounds such as flavonoids [98]. Phenolic compounds are also reported as natural antioxidants that can repair oxidative damage and has inhibitory activity 
against $\alpha$-glucosidase and $\alpha$-amylase enzymes [19,20]. It also has been reported [104] the involvement of several phenolic constitutions such as kaempferol, quercetin 3-rutinoside, and quercetin 3-rhamnoside (quercetin) in carbohydrate metabolism, reducing insulin resistance, dyslipidemia, and hyperglycemia. Insulin secretion in diabetic rats can be increased by p-coumaric acid. Moreover, elevated liver and muscle glycogen levels show better insulin activity in streptozotocin-induced diabetic rats [104,105].

In flowers, several antidiabetic activities has been found and listed in Table 7. The phenolic components of the D. volubilis flower extract are reported to provide hypoglycemic effects and therapeutic benefits. This is related to the results of the enzyme activity test involved in the digestion process, namely the IC50 value of $D$. volubilis were $2780.09 \pm 21.19 \mu \mathrm{g} / \mathrm{mL}$ in inhibiting $\alpha$-glucosidase and $360.68 \pm 1.26 \mu \mathrm{g} / \mathrm{mL}$ in $\alpha$-amylase [20]. Rutin compound in Dianthus calocephalus Boiss provides high inhibitory activity on $\alpha$-glucosidase [106].

Table 7. Antidiabetic activities in edible flowers.

\begin{tabular}{ccccc}
\hline Edible Flower & Compounds & Assessment & Activities & Ref. \\
\hline $\begin{array}{c}\text { Chrysanthemum morifolium } \\
\text { Ramat }\end{array}$ & $\begin{array}{c}\text { Chlorogenic acid and } \\
\text { luteolin }\end{array}$ & In vivo & $\begin{array}{c}\text { Reduced blood glucose level, } \\
\text { inhibited MCP-1 production }\end{array}$ \\
[ianthus calocephalus Boiss & Rutin & $\begin{array}{c}\text { In vitro enzymes } \\
\text { inhibitory }\end{array}$ & Inhibited $\alpha$-glucosidase \\
Dregea volubilis & $\begin{array}{c}\text { Gallic acid, ferulic acid, rutin, } \\
\text { ellagic acid, quercetin, } \\
\text { cinnamic acid }\end{array}$ & $\begin{array}{c}\text { In vitro enzymes } \\
\text { inhibitory }\end{array}$ & $\begin{array}{c}\text { Inhibited } \alpha \text {-glucosidase and } \\
\alpha \text {-amylase }\end{array}$ \\
[106] & [20] \\
Musa sp. Var. elakki bale & Phenolics (not specific) & In vivo & Inhibited AGEs formation & [45] \\
\hline
\end{tabular}

Not only doe edible flowers inhibit $\alpha$-glucosidase and $\alpha$-amylase, but they can also inhibit the formation of certain compounds. Evaluation of administration of flower extracts in obese diabetic mice was carried out. Animal models were given the AIN-93 M diet containing $1 \%$ and $5 \%$ of Chrysanthemum morifolium (CM) flower extracts for 5 weeks. The result showed that $\mathrm{CM}$ flower extract inhibited the production of MCP-1 (monocyte chemoattractant protein-1). MCP-1 plays an important role in inflammation, which produces tissue with insulin resistance [107]. Musa sp. var. Elakki bale is also reported to inhibit the formation of AGEs (advanced glycation end-products). The accumulation of AGEs can cause complications in diabetics, for example, kidney failure [44].

\section{Uricosuric Agent}

Uricosuric such as benzbromarone and probenecid are a class of drugs commonly used for the treatment of hyperuricemia. This condition is characterized by increased uric acid production, decreased excretion by the kidneys, or a combination of both, which causes high levels of uric acid in the blood [108,109]. High uric acid production and poor excretion system can cause the accumulation of uric acid crystals (monosodium urate). This occurs in the joints so that it can be at risk for arthritis Gout. Not only that, other risk factors such as hypertension, atherosclerosis, diabetes are also reported as a result of high uric acid levels $[110,111]$.

Uric acid is an organic compound produced through purine metabolic pathways [109]. There are two sources of purines, namely purines that are naturally produced by the body (endogenous) such as liver, intestine, other tissues like kidneys, muscles, and vascular endothelium, and then exogenous purines derived from food intake such as plant or animal foods [112,113].

The formation of uric acid involves xanthine oxidase (XO) enzyme, adenine, and guanine. First, adenosine monophosphate (AMP) is converted to inosine (as an intermediate product) through the process of deamination and dephosphorylation by nucleotidase, then guanine monophosphate (GMP) is converted to guanosine by nucleotidase. Nucleoside phosphorylase (PNP) will convert inosine and guanosine to hypoxanthine and guanine. 
Furthermore, hypoxanthine is converted to xanthine by $\mathrm{XO}$, while guanine becomes xanthine through a deamination process. Finally, uric acid is formed from xanthine due to xanthine oxidase oxidation [113]. AMP and GMP are purine nucleotides that contain bases hypoxanthine.

Treatments that can be done to control uric acid levels in the blood include suppressing production by inhibiting the action of the $\mathrm{XO}$ enzyme, regulating reabsorption and secretion in the kidneys. Allopurinol and febuxostat are $\mathrm{XO}$ inhibitors that are reported as a common approach to hyperuricemia [21]. Several studies have reported that treatment with $\mathrm{XO}$ inhibitors not only beneficial effects on the kidneys but also edematous brain, coronary ischemia, liver disorders, atherosclerosis and can improve endothelial function [114]. Unfortunately, people with allopurinol hypersensitivity can experience a skin rash, toxic epidermal necrolysis, erythematous rash, fever, hepatitis, and acute renal failure during allopurinol consumption. Moreover, it also can induce hepatotoxicity related to benzbromarone, so the idea of anti-hyperuricemia therapy that is safe and can minimize side effects is needed [21,115].

Several studies have reported that the involvement of phenolic compounds in the inhibition of xanthine oxidase (XO) and given that phenolic is a good bioactive source. [110] conducted a study of several phenolic compounds that were associated with enzyme inhibitory activity. The results showed that phenolic compounds such as ferulic, gallic and caffeic acid have the potential to inhibit XO. It also provides anti-inflammatory activity. In addition, in silico drug and SAR (structure-activity relationship) tests were carried out to qualify whether the compound could be used as a drug candidate or not. The results showed that the compound of ferulic, gallic, caffeic, and sinapic acid had good drug scores, confirmed to be safe for intake and non-mutagenic.

In flowers, the beneficial effects on the prevention or healing of hyperuricemia may still be minimal (listed in Table 8). Chrysanthemum sinense, which contains luteolin, diosmetin, apigenin, caffeic acid, etc., is very good at inhibiting XO enzyme after being tested in vitro [116]. Even in the in vivo test, Chrysanthemum indicum Linne, which contains coumarin, trans-cinnamic acid, etc., can reduce serum uric acid levels [117]. Moreover, the flavonoids in Hibiscus sabdariffa L. are also able to reduce uric acid levels in the body by providing a diuretic effect [118]. However, seeing the results shown above, it may be that phenolic compounds from various edible flowers also have potential as uricosuric agents, and this needs further research.

Table 8. Uricosuric activities in edible flowers.

\begin{tabular}{|c|c|c|c|c|}
\hline Edible Flower & Compounds & Assessment & Activities & Ref. \\
\hline $\begin{array}{c}\text { Chrysanthemum indicum } \\
\text { Linné }\end{array}$ & Coumarin, trans-cinnamic acid & In vivo & $\begin{array}{l}\text { Lowering serum uric } \\
\text { acid levels }\end{array}$ & [116] \\
\hline Chrysanthemum sinense & Luteolin, diosmetin, apigenin, caffeic acid & $\begin{array}{l}\text { In vitro enzyme } \\
\text { inhibitory }\end{array}$ & Inhibition XO enzyme & [117] \\
\hline Hibiscus sabdariffa $\mathrm{L}$. & $\begin{array}{l}\text { delphinidin-3-O-sambubioside, } \\
\text { cyanidin-3-O-sambubioside, quercetin, } \\
\text { rutin, chlorogenic acid }\end{array}$ & In vivo & Diuretic effect & [65] \\
\hline
\end{tabular}

\section{Anti-Hemolytic}

Hemolysis is the release of hemoglobin into the surrounding environment due to the rupture of the erythrocyte membrane of red blood cells (RBC). Hemolysis can occur in vivo and in vitro. Hemolysis in vivo includes autoimmune hemolytic anemia, transfusion reactions, paroxysmal nocturnal hemoglobinuria (blood disorders due to genetic mutase), paroxysmal cold hemoglobinuria, infections, and in vitro, such as blood sampling, processing, or improper removal of specimens $[119,120]$.

Some cases, for example hypotonic hemolysis is an extreme condition in human erythrocytes caused by low extracellular osmotic pressure. To achieve balance, erythrocytes will absorb water from the extracellular medium. However, when excessed, causes swelling 
and cell rupture. Another case, erythrocyte membranes consist of polyunsaturated fatty acids that are susceptible to lipid peroxidation reactions. Peroxidation reactions can be mediated by the presence of free radicals that will form peroxyl radicals. Peroxidation of membrane lipids is a free-radical chain reaction, triggering the erythrocyte membrane to be quickly damaged and leading to hemolysis [121,122].

The phenolic content is known as a natural antioxidant that can provide a protective effect toward cell damage by acting as a reducing agent, hydrogen donators, free radical scavengers, and singlet oxygen quenchers $[121,123]$. Several substances such as butadiene, rutin, and flavonoids can stabilize erythrocyte membranes that undergo hypotonic hemolysis. It is also associated with the anti-inflammatory activity of triterpene compounds against cell membranes [124-126].

Table 9 compiles the antihemolytic activities in several edible flowers. Clitoria ternatea, known as butterfly pea flowers, had reported having some effects on hemolysis in erythrocytes with type $\mathrm{O}^{+}$blood [127]. The results showed that the concentration of 40-120 $\mu \mathrm{g} / \mathrm{mL}$ extract had a protective effect against hemolysis. Concentrations of $120 \mu \mathrm{g} / \mathrm{mL}$ extract provide almost $50 \%$ of the effect on reducing hemolysis. This can be attributed to the involvement of components contained in flower extracts, including gallic, syringic, 2-hydroxycinnamic, protocatechuic, 2,4 dihydroxybenzoic, $p$-coumaric, caffeic, ferulic, and ellagic acids, also several compounds from the flavonoid group such as quercetin-3rutinoside; procyanidin A2; epicatechin; and delphinidin-3-O-glucoside. Prunus avium that contains hydroxycinnamic acid, 5-O-caffeoylquinic acid, p-coumaric, quercetin, and kaempferol also inhibited hemoglobin oxidation [128].

Table 9. Antihemolytic activities in edible flowers.

\begin{tabular}{|c|c|c|c|c|}
\hline Edible Flower & Compounds & Assessment & Activities & Ref. \\
\hline Clitoria ternatea L. & $\begin{array}{c}\text { 2,4-Dihydroxybenzoic acid, } \\
\text { protocatechuic acid, caffeic acid, } \\
\text {-coumaric acid, procyanidin A2, } \\
\text { delphinidin-3-O-glucoside, ellagic acid }\end{array}$ & In vitro & $\begin{array}{l}\text { Reduction of hemolysis by altering } \\
\text { lipid packaging and protecting } \\
\text { against oxidative damage }\end{array}$ & [127] \\
\hline Prunus avium & $\begin{array}{l}\text { Hydroxycinnamic acid, } \\
\text { 5-O-caffeoylquinic acid, p-coumaric, } \\
\text { quercetin, kaempferol }\end{array}$ & In vitro & Inhibition hemoglobin oxidation & [128] \\
\hline Thymus satureioides & $\begin{array}{c}\text { Caffeic acid, rosmarinic acid, luteolin } \\
\text { 7-glycoside, hesperetin }\end{array}$ & In vitro & $\begin{array}{l}\text { Protect and stabilize erythrocyte } \\
\text { membrane from lesions }\end{array}$ & [129] \\
\hline
\end{tabular}

Anti-hemolytic assay can be done using 2,2'-azobis(2-amidinopropane) dihydrochloride (AAPH) as an initiator of peroxyl radicals that produce free radicals to induce erythrocyte damage. The aqueous extract of Thymus satureioides showed good activity against AAPH. They ameliorate the half time of hemolysis in rabbit blood [129].

\section{Conclusions}

Either ornamental or fruit flowers have chemical compounds that provide benefits for human health. They contain various compounds; macronutrients like carbohydrates, proteins, fats, and micronutrients like vitamins, minerals, phenolics. Those compounds make edible flowers have many functional properties such as antioxidant, anti-inflammatory, antimicrobial, anticancer, neuroprotective agent, antidiabetic, uricosuric agent, and antihemolytic agent. There are also various applications of edible flowers, including food and non-food product. Nowadays, there is an increasing demand for functional food from the global market, so it is necessary to study the processing of edible flowers in order to maintain the quality and produce functional foods from many kinds of edible flowers. 
Author Contributions: Conceptualization, M.P.; methodology, W.S., M.P.; validation, W.S., and M.P.; formal analysis, N.B.P.; investigation, N.B.P., and V.O.; writing-original draft preparation, N.B.P., and V.O.; writing - review and editing, W.S. and M.P.; supervision, W.S. and M.P.; funding acquisition, N.B.P. All authors have read and agreed to the published version of the manuscript.

Funding: This research was funded by the Faculty of Agricultural Technology, Gadjah Mada University, Indonesia, through Innovative Research Grant No. 1853/UN1/FTP.1.3/SET-D/KU/2020.

Acknowledgments: This report forms part of the activity carried out by N.B.P. and V.O. at the University of Cadiz, Spain, under the frame of Erasmus Mundus Master in Quality in Analytical Laboratories (EMQAL) supported by the Education, Audiovisual and Culture Executive Agency (EACEA).

Conflicts of Interest: The authors declare no conflict of interest.

\section{References}

1. Mlcek, J.; Rop, O. Fresh edible flowers of ornamental plants-A new source of nutraceutical foods. Trends Food Sci. Technol. 2011, 22, 561-569. [CrossRef]

2. Takahashi, J.A.; Rezende, F.A.G.G.; Moura, M.A.F.; Dominguete, L.C.B.; Sande, D. Edible flowers: Bioactive profile and its potential to be used in food development. Food Res. Int. 2020, 129. [CrossRef] [PubMed]

3. Gradinaru, G.; Biliaderis, C.G.; Kallithraka, S.; Kefalas, P.; Garcia-Viguera, C. Thermal stability of Hibiscus sabdariffa L. anthocyanins in solution and in solid state: Effects of copigmentation and glass transition. Food Chem. 2003, 83, 423-436. [CrossRef]

4. Maciel, L.G.; do Carmo, M.A.V.; Azevedo, L.; Daguer, H.; Molognoni, L.; de Almeida, M.M.; Granato, D.; Rosso, N.D. Hibiscus sabdariffa anthocyanins-rich extract: Chemical stability, in vitro antioxidant and antiproliferative activities. Food Chem. Toxicol. 2018, 113, 187-197. [CrossRef] [PubMed]

5. Fernandes, L.; Casal, S.; Pereira, J.A.; Saraiva, J.A.; Ramalhosa, E. Edible flowers: A review of the nutritional, antioxidant, antimicrobial properties and effects on human health. J. Food Compos. Anal. 2017, 60, 38-50. [CrossRef]

6. Braun, N.A.; Kohlenberg, B.; Sim, S.; Meier, M.; Hammerschmidt, F.J. Jasminum flexile flower absolute from India-A detailed comparison with three other jasmine absolutes. Nat. Prod. Commun. 2009, 4, 1239-1250. [CrossRef] [PubMed]

7. Sommano, S.; Kerdtongmee, P.; Chompoo, M.; Nisoa, M. Fabrication and characteristics of phase control microwave power for jasmine volatile oil extraction. J. Essent. Oil Res. 2015, 27, 316-323. [CrossRef]

8. Wathoni, N.; Haerani, A.; Yuniarsih, N.; Haryanti, R. A Review on Herbal Cosmetics in Indonesia. Int. J. Appl. Pharm. 2018, 10, 13. [CrossRef]

9. Adliani, N. Lipstick Formulation Using Natural Dye from Etlingera elatior (Jack) R.M.Sm. Extract. J. Pharm. Pharmacol. 2012, 1, 87-94. [CrossRef]

10. Chong, F.C.; Gwee, X.F. Ultrasonic extraction of anthocyanin from Clitoria ternatea flowers using response surface methodology. Nat. Prod. Res. 2015, 29, 1485-1487. [CrossRef]

11. Zakaria, N.N.A.; Okello, E.J.; Howes, M.J.; Birch-Machin, M.A.; Bowman, A. In vitro protective effects of an aqueous extract of Clitoria ternatea L. flower against hydrogen peroxide-induced cytotoxicity and UV-induced mtDNA damage in human keratinocytes. Phyther. Res. 2018, 32, 1064-1072. [CrossRef] [PubMed]

12. Qing, L.S.; Xue, Y.; Zhang, J.G.; Zhang, Z.F.; Liang, J.; Jiang, Y.; Liu, Y.M.; Liao, X. Identification of flavonoid glycosides in Rosa chinensis flowers by liquid chromatography-tandem mass spectrometry in combination with $13 \mathrm{C}$ nuclear magnetic resonance. $J$ Chromatogr. A 2012, 1249, 130-137. [CrossRef]

13. Pinakin, D.J.; Kumar, V.; Suri, S.; Sharma, R.; Kaushal, M. Nutraceutical potential of tree flowers: A comprehensive review on biochemical profile, health benefits, and utilization. Food Res. Int. 2020, 127, 108724. [CrossRef] [PubMed]

14. Zheng, J.; Meenu, M.; Xu, B. A systematic investigation on free phenolic acids and flavonoids profiles of commonly consumed edible flowers in China. J. Pharm. Biomed. Anal. 2019, 172, 268-277. [CrossRef] [PubMed]

15. Morais, S.G.G.; da Silva Campelo Borges, G.; dos Santos Lima, M.; Martín-Belloso, O.; Magnani, M. Effects of probiotics on the content and bioaccessibility of phenolic compounds in red pitaya pulp. Food Res. Int. 2019, 126, 108681. [CrossRef]

16. Manach, C.; Mazur, A.; Scalbert, A. Polyphenols and prevention of cardiovascular diseases. Curr. Opin. Lipidol. 2005, 16, 77-84. [CrossRef]

17. Baessa, M.; Rodrigues, M.J.; Pereira, C.; Santos, T.; da Rosa Neng, N.; Nogueira, J.M.F.; Barreira, L.; Varela, J.; Ahmed, H.; Asif, S.; et al. A comparative study of the in vitro enzyme inhibitory and antioxidant activities of Butea monosperma (Lam.) Taub. and Sesbania grandiflora (L.) Poiret from Pakistan: New sources of natural products for public health problems. S. Afr. J. Bot. 2019, 120, 146-156. [CrossRef]

18. Ghasemzadeh, A.; Jaafar, H.Z.E.; Rahmat, A.; Ashkani, S. Secondary metabolites constituents and antioxidant, anticancer and antibacterial activities of Etlingera elatior (Jack) R.M.Sm grown in different locations of Malaysia. BMC Complement. Altern. Med. 2015, 15, 1-10. [CrossRef]

19. Ang, L.Z.P.; Hashim, R.; Sulaiman, S.F.; Coulibaly, A.Y.; Sulaiman, O.; Kawamura, F.; Salleh, K.M. In vitro antioxidant and antidiabetic activites of Gluta torquata. Ind. Crop. Prod. 2015, 76, 755-760. [CrossRef] 
20. Das, B.; De, A.; Das, M.; Das, S.; Samanta, A. A new exploration of Dregea volubilis flowers: Focusing on antioxidant and antidiabetic properties. S. Afr. J. Bot. 2017, 109, 16-24. [CrossRef]

21. Lin, H.; Tu, C.; Niu, Y.; Li, F.; Yuan, L.; Li, N.; Xu, A.; Gao, L.; Li, L. Dual actions of norathyriol as a new candidate hypouricaemic agent: Uricosuric effects and xanthine oxidase inhibition. Eur. J. Pharmacol. 2019, 853, 371-380. [CrossRef]

22. Vauzour, D.; Vafeiadou, K.; Rodriguez-Mateos, A.; Rendeiro, C.; Spencer, J.P.E. The neuroprotective potential of flavonoids: A multiplicity of effects. Genes Nutr. 2008, 3, 115-126. [CrossRef]

23. Zhao, L.; Fan, H.; Zhang, M.; Chitrakar, B.; Bhandari, B.; Wang, B. Edible flowers: Review of flower processing and extraction of bioactive compounds by novel technologies. Food Res. Int. 2019, 126. [CrossRef]

24. Cavaiuolo, M.; Cocetta, G.; Ferrante, A. The antioxidants changes in ornamental flowers during development and senescence. Antioxidants 2013, 2, 132. [CrossRef]

25. Kaisoon, O.; Siriamornpun, S.; Weerapreeyakul, N.; Meeso, N. Phenolic compounds and antioxidant activities of edible flowers from Thailand. J. Funct. Foods 2011, 3, 88-99. [CrossRef]

26. Li, Z.; Lee, H.W.; Liang, X.; Liang, D.; Wang, Q.; Huang, D.; Ong, C.N. Profiling of phenolic compounds and antioxidant activity of 12 cruciferous vegetables. Molecules 2018, 23, 1139. [CrossRef]

27. Mahn, A.; Reyes, A. An overview of health-promoting compounds of broccoli (Brassica oleracea var. italica) and the effect of processing. Food Sci. Technol. Int. 2012, 18, 503-514. [CrossRef]

28. Abudunia, A.M.; Marmouzi, I.; Faouzi, M.E.A.; Ramli, Y.; Taoufik, J.; El Madani, N.; Essassi, E.M.; Salama, A.; Khedid, K.; Ansar, M.; et al. Activité anti-candidose, antibactérienne, cytotoxique et antioxydante des fleurs de Calendula arvensis. J. Mycol. Med. 2017, 27, 90-97. [CrossRef] [PubMed]

29. Ak, G.; Zengin, G.; Sinan, K.I.; Mahomoodally, M.F.; Picot-Allain, M.C.N.; Cakir, O.; Bensari, S.; Yilmaz, M.A.; Gallo, M.; Montesano, D. A comparative bio-evaluation and chemical profiles of Calendula officinalis L. extracts prepared via different extraction techniques. Appl. Sci. 2020, 10, 5920. [CrossRef]

30. Dwivedi, M.K.; Sonter, S.; Mishra, S.; Patel, D.K.; Singh, P.K. Antioxidant, antibacterial activity, and phytochemical characterization of Carica papaya flowers. Beni-Suef Univ. J. Basic Appl. Sci. 2020, 9. [CrossRef]

31. Degirmenci, H.; Erkurt, H. Chemical profile and antioxidant potency of Citrus aurantium L. flower extracts with antibacterial effect against foodborne pathogens in rice pudding. LWT 2020, 126, 109273. [CrossRef]

32. Azima, A.M.S.; Noriham, A.; Manshoor, N. Phenolics, antioxidants and color properties of aqueous pigmented plant extracts: Ardisia colorata var. elliptica, Clitoria ternatea, Garcinia mangostana and Syzygium cumini. J. Funct. Foods 2017, 38, 232-241. [CrossRef]

33. Renjith, R.S.; Chikku, A.M.; Rajamohan, T. Cytoprotective, antihyperglycemic and phytochemical properties of Cocos nucifera (L.) inflorescence. Asian Pac. J. Trop. Med. 2013, 6, 804-810. [CrossRef]

34. Chithra, M.A.; Ijinu, T.P.; Kharkwal, H.; Sharma, R.K.; Janardhanan, K.K.; Pushpangadan, P.; George, V. Cocos nucifera L. Inflorescence extract: An effective hepatoprotective agent. Indian J. Tradit. Knowl. 2020, 19, 128-136.

35. Aliyazicioglu, R.; Demir, S.; Badem, M.; Sener, S.O.; Korkmaz, N.; Demir, E.A.; Ozgen, U.; Karaoglu, S.A.; Aliyazicioglu, Y. Antioxidant, antigenotoxic, antimicrobial activities and phytochemical analysis of Dianthus carmelitarum. Rec. Nat. Prod. 2017, 11, 270-284.

36. Ho, S.C.; Hwang, L.S.; Shen, Y.J.; Lin, C.C. Suppressive effect of a proanthocyanidin-rich extract from longan (Dimocarpus longan Lour.) flowers on nitric oxide production in lps-stimulated macrophage cells. J. Agric. Food Chem. 2007, 55, 10664-10670. [CrossRef]

37. Hsieh, M.C.; Shen, Y.J.; Kuo, Y.H.; Hwang, L.S. Antioxidative activity and active components of longan (Dimocarpus longan Lour.) flower extracts. J. Agric. Food Chem. 2008, 56, 7010-7016. [CrossRef] [PubMed]

38. Anzian, A.; Rashidah, S.; Saari, N.; Sapawi, C.W.N.S.; Meor Hussin, A.S. Chemical composition and antioxidant activity of Torch Ginger (Etlingera elatior) flower extract. Food Appl. Biosci. J. 2017, 5, 32-49.

39. Anokwuru, C.P.; Esiaba, I.; Ajbaye, O.; Adesuyi, A.O. Polyphenolic Content and Antioxidant Activity of Hibiscus sabdariffa Calyx. Res. J. Med. Plant 2011, 5, 557-566. [CrossRef]

40. Fernández-Arroyo, S.; Rodríguez-Medina, I.C.; Beltrán-Debón, R.; Pasini, F.; Joven, J.; Micol, V.; Segura-Carretero, A.; FernándezGutiérrez, A. Quantification of the polyphenolic fraction and in vitro antioxidant and in vivo anti-hyperlipemic activities of Hibiscus sabdariffa aqueous extract. Food Res. Int. 2011, 44, 1490-1495. [CrossRef]

41. Piovesana, A.; Rodrigues, E.; Noreña, C.P.Z. Composition analysis of carotenoids and phenolic compounds and antioxidant activity from hibiscus calyces (Hibiscus sabdariffa L.) by HPLC-DAD-MS/MS. Phytochem. Anal. 2019, 30, 208-217. [CrossRef]

42. Alhakmani, F.; Kumar, S.; Khan, S.A. Estimation of total phenolic content, in-vitro antioxidant and anti-inflammatory activity of flowers of Moringa oleifera. Asian Pac. J. Trop. Biomed. 2013, 3, 623-627. [CrossRef]

43. Begum, Y.A.; Deka, S.C. Chemical profiling and functional properties of dietary fibre rich inner and outer bracts of culinary banana flower. J. Food Sci. Technol. 2019, 56, 5298-5308. [CrossRef] [PubMed]

44. Bhaskar, J.J.; Mahadevamma, S.; Chilkunda, N.D.; Salimath, P.V. Banana (Musa sp. var. elakki bale) flower and pseudostem: Dietary fiber and associated antioxidant capacity. J. Agric. Food Chem. 2012, 60, 427-432. [CrossRef] [PubMed]

45. Bhaskar, J.J.; Shobha, M.S.; Sambaiah, K.; Salimath, P.V. Beneficial effects of banana (Musa sp. var. elakki bale) flower and pseudostem on hyperglycemia and advanced glycation end-products (AGEs) in streptozotocin-induced diabetic rats. J. Physiol. Biochem. 2011, 67, 415-425. [CrossRef] 
46. Baydar, N.G.; Baydar, H. Phenolic compounds, antiradical activity and antioxidant capacity of oil-bearing rose (Rosa damascena Mill.) extracts. Ind. Crops Prod. 2013, 41, 375-380. [CrossRef]

47. Navarro-González, I.; González-Barrio, R.; García-Valverde, V.; Bautista-Ortín, A.B.; Periago, M.J. Nutritional composition and antioxidant capacity in edible flowers: Characterisation of phenolic compounds by HPLC-DAD-ESI/MSn. Int. J. Mol. Sci. 2015, 16, 805. [CrossRef]

48. González-Barrio, R.; Periago, M.J.; Luna-Recio, C.; Garcia-Alonso, F.J.; Navarro-González, I. Chemical composition of the edible flowers, pansy (Viola wittrockiana) and snapdragon (Antirrhinum majus) as new sources of bioactive compounds. Food Chem. 2018, 252, 373-380. [CrossRef]

49. Moliner, C.; Barros, L.; Dias, M.I.; Reigada, I.; Ferreira, I.C.F.R.; López, V.; Langa, E.; Rincón, C.G. Viola cornuta and Viola x wittrockiana: Phenolic compounds, antioxidant and neuroprotective activities on Caenorhabditis elegans. J. Food Drug Anal. 2019, 27, 849-859. [CrossRef] [PubMed]

50. Fernandes, L.; Casal, S.I.P.; Pereira, J.A.; Ramalhosa, E.; Saraiva, J.A. Optimization of high pressure bioactive compounds extraction from pansies (Viola $\times$ wittrockiana) by response surface methodology. High Press. Res. 2017, 37, 415-429. [CrossRef]

51. Brglez Mojzer, E.; Knez Hrnčič, M.K.; Škerget, M.; Knez, Ž.; Bren, U. Polyphenols: Extraction methods, antioxidative action, bioavailability and anticarcinogenic effects. Molecules 2016, 21, 901. [CrossRef] [PubMed]

52. Sultana, K.; Jayathilakan, K.; Pandey, M.C. Evaluation of Antioxidant Activity, Radical Scavenging, and Reducing Power of Clove Oil and Clove Oleoresin in Comparison with Natural and Synthetic Antioxidants in Chevon (Capra aegagrus hircus) and Chicken Meat. Def. Life Sci. J. 2017, 3, 51. [CrossRef]

53. Li, A.N.; Li, S.; Li, H.B.; Xu, D.P.; Xu, X.R.; Chen, F. Total phenolic contents and antioxidant capacities of 51 edible and wild flowers. J. Funct. Foods 2014, 6, 319-330. [CrossRef]

54. Mao, L.C.; Pan, X.; Que, F.; Fang, X.H. Antioxidant properties of water and ethanol extracts from hot air-dried and freeze-dried daylily flowers. Eur. Food Res. Technol. 2006, 222, 236-241. [CrossRef]

55. Jajic, I.; Sarna, T.; Strzalka, K. Senescence, stress, and reactive oxygen species. Plants 2015, 4, 393. [CrossRef] [PubMed]

56. Chu, Y.F.; Sun, J.; Wu, X.; Liu, R.H. Antioxidant and antiproliferative activities of common vegetables. J. Agric. Food Chem. 2002, 50, 6910-6916. [CrossRef]

57. Ismail, A.; Marjan, Z.M.; Foong, C.W. Total antioxidant activity and phenolic content in selected vegetables. Food Chem. 2004, 87, 581-586. [CrossRef]

58. Yang, J.; Liu, X.; Zhang, X.; Jin, Q.; Li, J. Phenolic Profiles, Antioxidant Activities, and Neuroprotective Properties of Mulberry (Morus atropurpurea Roxb.) Fruit Extracts from Different Ripening Stages. J. Food Sci. 2016, 81, C2439-C2446. [CrossRef] [PubMed]

59. Lu, B.; Li, M.; Yin, R. Phytochemical Content, Health Benefits, and Toxicology of Common Edible Flowers: A Review (2000-2015). Crit. Rev. Food Sci. Nutr. 2016, 56, S130-S148. [CrossRef]

60. Kim, K.S.; Lee, D.S.; Bae, G.S.; Park, S.J.; Kang, D.G.; Lee, H.S.; Oh, H.; Kim, Y.C. The inhibition of JNK MAPK and NF-кB signaling by tenuifoliside A isolated from Polygala tenuifolia in lipopolysaccharide-induced macrophages is associated with its anti-inflammatory effect. Eur. J. Pharmacol. 2013, 721, 267-276. [CrossRef]

61. Nahar, P.P.; Driscoll, M.V.; Li, L.; Slitt, A.L.; Seeram, N.P. Phenolic mediated anti-inflammatory properties of a maple syrup extract in RAW 264.7 murine macrophages. J. Funct. Foods 2014, 6, 126-136. [CrossRef]

62. Oh, Y.C.; Cho, W.K.; Jeong, Y.H.; Im, G.Y.; Lee, K.J.; Yang, H.J.; Ma, J.Y. Anti-inflammatory effect of Sosihotang via inhibition of nuclear factor- $\mathrm{KB}$ and mitogen-activated protein kinases signaling pathways in lipopolysaccharide-stimulated RAW 264.7 macrophage cells. Food Chem. Toxicol. 2013, 53, 343-351. [CrossRef]

63. An, H.J.; Kim, I.T.; Park, H.J.; Kim, H.M.; Choi, J.H.; Lee, K.T. Tormentic acid, a triterpenoid saponin, isolated from Rosa rugosa, inhibited LPS-induced iNOS, COX-2, and TNF- $\alpha$ expression through inactivation of the nuclear factor-kb pathway in RAW 264.7 macrophages. Int. Immunopharmacol. 2011, 11, 504-510. [CrossRef]

64. Shao, J.; Li, Y.; Wang, Z.; Xiao, M.; Yin, P.; Lu, Y.; Qian, X.; Xu, Y.; Liu, J. 7b, a novel naphthalimide derivative exhibited antiinflammatory effects via targeted-inhibiting TAK1 following down-regulation of ERK1/2- and p38 MAPK-mediated activation of NF-кB in LPS-stimulated RAW264.7 macrophages. Int. Immunopharmacol. 2013, 17, 216-228. [CrossRef]

65. Beltrán-Debón, R.; Alonso-Villaverde, C.; Aragonès, G.; Rodríguez-Medina, I.; Rull, A.; Micol, V.; Segura-Carretero, A.; FernándezGutiérrez, A.; Camps, J.; Joven, J. The aqueous extract of Hibiscus sabdariffa calices modulates the production of monocyte chemoattractant protein-1 in humans. Phytomedicine 2010, 17, 186-191. [CrossRef] [PubMed]

66. Sogo, T.; Terahara, N.; Hisanaga, A.; Kumamoto, T.; Yamashiro, T.; Wu, S.; Sakao, K.; Hou, D.X. Anti-inflammatory activity and molecular mechanism of delphinidin 3-sambubioside, a Hibiscus anthocyanin. BioFactors 2015, 41, 58-65. [CrossRef]

67. Tursun, X.; Zhao, Y.; Alat, Z.; Xin, X.; Tursun, A.; Abdulla, R.; Akber Aisa, H. Anti- inflammatory effect of Rosa rugosa flower extract in lipopolysaccharide-stimulated RAW264.7 macrophages. Biomol. Ther. 2016, 24, 184-190. [CrossRef] [PubMed]

68. Krolikiewicz-Renimel, I.; Michel, T.; Destandau, E.; Reddy, M.; André, P.; Elfakir, C.; Pichon, C. Protective effect of a Butea monosperma (Lam.) Taub. flowers extract against skin inflammation: Antioxidant, anti-inflammatory and matrix metalloproteinases inhibitory activities. J. Ethnopharmacol. 2013, 148, 537-543. [CrossRef] [PubMed]

69. Li, M.; Li, B.; Hou, Y.; Tian, Y.; Chen, L.; Liu, S.; Zhang, N.; Dong, J. Anti-inflammatory effects of chemical components from Ginkgo biloba L. male flowers on lipopolysaccharide-stimulated RAW264.7 macrophages. Phyther. Res. 2019, 33, 989-997. [CrossRef]

70. Loganayaki, N.; Suganya, N.; Manian, S. Evaluation of edible flowers of agathi (Sesbania grandiflora L. Fabaceae) for in vivo anti-inflammatory and analgesic, and in vitro antioxidant potential. Food Sci. Biotechnol. 2012, 21, 509-517. [CrossRef] 
71. China, R.; Mukherjee, S.; Sen, S.; Bose, S.; Datta, S.; Koley, H.; Ghosh, S.; Dhar, P. Antimicrobial activity of Sesbania grandiflora flower polyphenol extracts on some pathogenic bacteria and growth stimulatory effect on the probiotic organism Lactobacillus acidophilus. Microbiol. Res. 2012, 167, 500-506. [CrossRef]

72. Nowak, R.; Olech, M.; Pecio, L.; Oleszek, W.; Los, R.; Malm, A.; Rzymowska, J. Cytotoxic, antioxidant, antimicrobial properties and chemical composition of rose petals. J. Sci. Food Agric. 2014, 94, 560-567. [CrossRef]

73. Hashemi, S.M.B.; Amininezhad, R.; Shirzadinezhad, E.; Farahani, M.; Yousefabad, S.H.A. The Antimicrobial and Antioxidant Effects of Citrus aurantium L. Flowers (Bahar Narang) Extract in Traditional Yoghurt Stew during Refrigerated Storage. J. Food Saf. 2016, 36, 153-161. [CrossRef]

74. Sitthiya, K.; Devkota, L.; Sadiq, M.B.; Anal, A.K. Extraction and characterization of proteins from banana (Musa Sapientum L) flower and evaluation of antimicrobial activities. J. Food Sci. Technol. 2018, 55, 658-666. [CrossRef] [PubMed]

75. Al-hashimi, A.G. Antioxidant and antibacterial activities of Hibiscus sabdariffa L. extracts. Afr. J. Food Sci. 2012, 6, 506-511. [CrossRef]

76. Valsalam, S.; Agastian, P.; Esmail, G.A.; Ghilan, A.K.M.; Al-Dhabi, N.A.; Arasu, M.V. Biosynthesis of silver and gold nanoparticles using Musa acuminata colla flower and its pharmaceutical activity against bacteria and anticancer efficacy. J. Photochem. Photobiol. B Biol. 2019, 201. [CrossRef]

77. Cristóvão, M.B.; Janssens, R.; Yadav, A.; Pandey, S.; Luis, P.; van der Bruggen, B.; Dubey, K.K.; Mandal, M.K.; Crespo, J.G.; Pereira, V.J. Predicted concentrations of anticancer drugs in the aquatic environment: What should we monitor and where should we treat? J. Hazard. Mater. 2020, 392. [CrossRef]

78. Bray, F.; Ferlay, J.; Soerjomataram, I.; Siegel, R.L.; Torre, L.A.; Jemal, A. Global cancer statistics 2018: GLOBOCAN estimates of incidence and mortality worldwide for 36 cancers in 185 countries. CA Cancer J. Clin. 2018, 68, 394-424. [CrossRef]

79. Liu, H.; Ma, L.; Lin, J.; Cao, B.; Qu, D.; Luo, C.; Huang, W.; Han, L.; Xu, H.; Wu, Z.; et al. Advances in molecular mechanisms of drugs affecting abnormal glycosylation and metastasis of breast cancer. Pharmacol. Res. 2020, 155. [CrossRef]

80. Gawlik-Dziki, U.; Jeżyna, M.; Świeca, M.; Dziki, D.; Baraniak, B.; Czyż, J. Effect of bioaccessibility of phenolic compounds on in vitro anticancer activity of broccoli sprouts. Food Res. Int. 2012, 49, 469-476. [CrossRef]

81. Wu, W.S. The signaling mechanism of ROS in tumor progression. Cancer Metastasis Rev. 2006, 25, 695-705. [CrossRef]

82. Salehi, B.; Vlaisavljevic, S.; Adetunji, C.O.; Adetunji, J.B.; Kregiel, D.; Antolak, H.; Pawlikowska, E.; Uprety, Y.; Mileski, K.S.; Devkota, H.P.; et al. Plants of the genus Vitis: Phenolic compounds, anticancer properties and clinical relevance. Trends Food Sci. Technol. 2019, 91, 362-379. [CrossRef]

83. Georgiev, V.; Ananga, A.; Tsolova, V. Recent advances and uses of grape flavonoids as nutraceuticals. Nutrients 2014, 6, 391. [CrossRef]

84. Yang, C.S.; Landau, J.M.; Huang, M.; Newmark, H.L. Inhibition of Carcinogenesis by Dietary Polyphenolic Compounds. Annu. Rev. Nutr. 2001, 21, 381-406. [CrossRef] [PubMed]

85. Vajrabhaya, L.O.; Korsuwannawong, S. Cytotoxicity evaluation of a Thai herb using tetrazolium (MTT) and sulforhodamine B (SRB) assays. J. Anal. Sci. Technol. 2018, 9. [CrossRef]

86. Cruceriu, D.; Diaconeasa, Z.; Socaci, S.; Socaciu, C.; Rakosy-Tican, E.; Balacescu, O. Biochemical profile, selective cytotoxicity and molecular effects of Calendula officinalis extracts on breast cancer cell lines. Not. Bot. Horti Agrobot. 2020, 48, 24-39. [CrossRef]

87. Nga, V.T.; Trang, N.T.H.; Tuyet, N.T.A.; Phung, N.K.P.; Duong, N.T.T.; Thu, N.T.H. Ethanol extract of male Carica papaya flowers demonstrated non-toxic against MCF-7, HEP-G2, HELA, NCI-H460 cancer cell lines. Vietnam J. Chem. 2020, 58, 86-91. [CrossRef]

88. Zan, C.H.; Rahmat, A.; Akim, A.M.; Alitheen, N.B.M.; Othman, F.; Lian, G.E.C. Anti-proliferative effects of pandan leaves (Pandanus amarylfolius), kantan flower (Etlingera elatior) and turmeric leaves (Curcuma longa). Nutr. Food Sci. 2011, 41, 238-241. [CrossRef]

89. Timsina, B.; Nadumane, V.K. Anti-cancer potential of banana flower extract: An in vitro study. Bangladesh J. Pharmacol. 2014, 9, 628-635. [CrossRef]

90. Fachel, F.N.S.; Schuh, R.S.; Veras, K.S.; Bassani, V.L.; Koester, L.S.; Henriques, A.T.; Braganhol, E.; Teixeira, H.F. An overview of the neuroprotective potential of rosmarinic acid and its association with nanotechnology-based delivery systems: A novel approach to treating neurodegenerative disorders. Neurochem. Int. 2019, 122, 47-58. [CrossRef]

91. Harnett, J.J.; Roubert, V.; Dolo, C.; Charnet, C.; Spinnewyn, B.; Cornet, S.; Rolland, A.; Marin, J.-G.; Bigg, D.; Chabrier, P.-E. Phenolic thiazoles as novel orally-active neuroprotective agents. Bioorg. Med. Chem. Lett. 2004, 14, 157-160. [CrossRef]

92. Solanki, I.; Parihar, P.; Parihar, M.S. Neurodegenerative diseases: From available treatments to prospective herbal therapy. Neurochem. Int. 2016, 95, 100-108. [CrossRef] [PubMed]

93. Iriti, M.; Vitalini, S.; Fico, G.; Faoro, F. Neuroprotective herbs and foods from different traditional medicines and diets. Molecules 2010, 15, 3517. [CrossRef]

94. Hong-Qi, Y.; Zhi-Kun, S.; Sheng-Di, C. Current advances in the treatment of Alzheimer's disease: Focused on considerations targeting A $\beta$ and tau. Transl. Neurodegener. 2012, 1, 21. [CrossRef] [PubMed]

95. Khan, H.; Ullah, H.; Aschner, M.; Cheang, W.S.; Akkol, E.K. Neuroprotective effects of quercetin in alzheimer's disease. Biomolecules 2020, 10, 59. [CrossRef] [PubMed]

96. Shimmyo, Y.; Kihara, T.; Akaike, A.; Niidome, T.; Sugimoto, H. Flavonols and flavones as BACE-1 inhibitors: Structure-activity relationship in cell-free, cell-based and in silico studies reveal novel pharmacophore features. Biochim. Biophys. Acta Gen. Subj. 2008, 1780, 819-825. [CrossRef] [PubMed] 
97. Maggi, M.A.; Bisti, S.; Picco, C. Saffron: Chemical Composition and Neuroprotective Activity. Molecules 2020, 25, 5618. [CrossRef]

98. Tang, X.; Olatunji, O.J.; Zhou, Y.; Hou, X. Allium tuberosum: Antidiabetic and hepatoprotective activities. Food Res. Int. 2017, 102, 681-689. [CrossRef]

99. Taslimi, P.; Köksal, E.; Gören, A.C.; Bursal, E.; Aras, A.; Kılıç, Ö.; Alwasel, S.; Gülçin, İ. Anti-Alzheimer, antidiabetic and antioxidant potential of Satureja cuneifolia and analysis of its phenolic contents by LC-MS/MS. Arab. J. Chem. 2019, 13, 4528-4537. [CrossRef]

100. Figueiredo-González, M.; Reboredo-Rodríguez, P.; González-Barreiro, C.; Simal-Gándara, J.; Valentão, P.; Carrasco-Pancorbo, A.; Andrade, P.B.; Cancho-Grande, B. Evaluation of the neuroprotective and antidiabetic potential of phenol-rich extracts from virgin olive oils by in vitro assays. Food Res. Int. 2018, 106, 558-567. [CrossRef]

101. Fowler, M.J. Microvascular and macrovascular complications of diabetes. Clin. Diabetes 2011, 29, 116-122. [CrossRef]

102. Sajid, M.; Khan, M.R.; Ismail, H.; Latif, S.; Rahim, A.A.; Mehboob, R.; Shah, S.A. Antidiabetic and antioxidant potential of Alnus nitida leaves in alloxan induced diabetic rats. J. Ethnopharmacol. 2020, 251. [CrossRef] [PubMed]

103. Wang, S.; Zhu, F. Antidiabetic dietary materials and animal models. Food Res. Int. 2016, 85, 315-331. [CrossRef]

104. da Silva, C.P.; Soares-Freitas, R.A.M.; Sampaio, G.R.; Santos, M.C.B.; do Nascimento, T.P.; Cameron, L.C.; Ferreira, M.S.L.; Arêas, J.A.G. Identification and action of phenolic compounds of Jatobá-do-cerrado (Hymenaea stignocarpa Mart.) on $\alpha$-amylase and $\alpha$-glucosidase activities and flour effect on glycemic response and nutritional quality of breads. Food Res. Int. 2018, 116, 1076-1083. [CrossRef]

105. Shairibha, S.M.R.; Rajadurai, M.; Kumar, N. Effect of Root Kudzu on Biochemical Parameters in Streptozotocin-Induced Diabetic Rats. J. Knowl. Health 2015, 10, 18-23. [CrossRef]

106. Uysal, S.; Aktumsek, A.; Picot-Allain, C.M.N.; Unuvar, H.; Mollica, A.; Georgiev, M.I.; Zengin, G.; Mahomoodally, M.F. Biological, chemical and in silico fingerprints of Dianthus calocephalus Boiss.: A novel source for rutin. Food Chem. Toxicol. 2018, 113, 179-186. [CrossRef] [PubMed]

107. Yamamoto, J.; Tadaishi, M.; Yamane, T.; Oishi, Y.; Shimizu, M.; Kobayashi-Hattori, K. Hot water extracts of edible Chrysanthemum morifolium Ramat. Exert antidiabetic effects in obese diabetic KK-Ay mice. Biosci. Biotechnol. Biochem. 2015, 79, 1147-1154. [CrossRef]

108. Hori, T.; Ouchi, M.; Otani, N.; Nohara, M.; Morita, A.; Otsuka, Y.; Jutabha, P.; Shibasaki, I.; Matsushita, Y.; Fujita, T.; et al. The uricosuric effects of dihydropyridine calcium channel blockers in vivo using urate under-excretion animal models. J. Pharmacol. Sci. 2018, 136, 196-202. [CrossRef] [PubMed]

109. Lee, Y.S.; Sung, Y.Y.; Yuk, H.J.; Son, E.; Lee, S.J.; Kim, J.S.; Kim, D.S. Anti-hyperuricemic effect of Alpinia oxyphylla seed extract by enhancing uric acid excretion in the kidney. Phytomedicine 2019, 62. [CrossRef] [PubMed]

110. Nile, S.H.; Ko, E.Y.; Kim, D.H.; Keum, Y.S. Screening of ferulic acid related compounds as inhibitors of xanthine oxidase and cyclooxygenase-2 with anti-inflammatory activity. Braz. J. Pharmacogn. 2016, 26, 50-55. [CrossRef]

111. Wu, L.; Sun, Z.; Chen, A.; Guo, X.; Wang, J. Effect of astaxanthin and exercise on antioxidant capacity of human body, blood lactic acid and blood uric acid metabolism. Sci. Sports 2019, 34, 348-352. [CrossRef]

112. Chaudhary, K.; Malhotra, K.; Sowers, J.; Aroor, A. Uric acid-key ingredient in the recipe for cardiorenal metabolic syndrome. Cardiorenal Med. 2013, 3, 208-220. [CrossRef]

113. Maiuolo, J.; Oppedisano, F.; Gratteri, S.; Muscoli, C.; Mollace, V. Regulation of uric acid metabolism and excretion. Int. J. Cardiol. 2016, 213, 8-14. [CrossRef] [PubMed]

114. Kushiyama, A.; Nakatsu, Y.; Matsunaga, Y.; Yamamotoya, T.; Mori, K.; Ueda, K.; Inoue, Y.; Sakoda, H.; Fujishiro, M.; Ono, H.; et al. Role of uric acid metabolism-related inflammation in the pathogenesis of metabolic syndrome components such as atherosclerosis and nonalcoholic steatohepatitis. Mediators Inflamm. 2016, 2016. [CrossRef] [PubMed]

115. Chaichian, Y.; Chohan, S.; Becker, M.A. Long-term management of gout: Nonpharmacologic and pharmacologic therapies. Rheum. Dis. Clin. N. Am. 2014, 40, 357-374. [CrossRef]

116. Lee, Y.S.; Son, E.; Kim, S.H.; Lee, Y.M.; Kim, O.S.; Kim, D.S. Synergistic Uric Acid-Lowering Effects of the Combination of Chrysanthemum indicum Linne Flower and Cinnamomum cassia (L.) J. Persl Bark Extracts. Evidence-Based Complement. Altern. Med. 2017, 2017. [CrossRef]

117. Nguyen, M.T.T.; Awale, S.; Tezuka, Y.; Ueda, J.Y.; Le Tran, Q.; Kadota, S. Xanthine oxidase inhibitors from the flowers of Chrysanthemum sinense. Planta Med. 2006, 72, 46-51. [CrossRef] [PubMed]

118. Alarcón-Alonso, J.; Zamilpa, A.; Aguilar, F.A.; Herrera-Ruiz, M.; Tortoriello, J.; Jimenez-Ferrer, E. Pharmacological characterization of the diuretic effect of Hibiscus sabdariffa Linn (Malvaceae) extract. J. Ethnopharmacol. 2012, 139, 751-756. [CrossRef] [PubMed]

119. Feitosa, V.A.; de Almeida, V.C.; Malheiros, B.; de Castro, R.D.; Barbosa, L.R.S.; Cerize, N.N.P.; Rangel-Yagui, C.D.O. Polymeric micelles of pluronic F127 reduce hemolytic potential of amphiphilic drugs. Colloids Surf. B Biointerfaces 2019, 180, 177-185. [CrossRef]

120. Shah, K.G.; Idrovo, J.P.; Nicastro, J.; McMullen, H.F.; Molmenti, E.P.; Coppa, G. A retrospective analysis of the incidence of hemolysis in type and screen specimens from trauma patients. Int. J. Angiol. 2009, 18, 182-183. [CrossRef]

121. Costa, R.M.; Magalhães, A.S.; Pereira, J.A.; Andrade, P.B.; Valentão, P.; Carvalho, M.; Silva, B.M. Evaluation of free radicalscavenging and antihemolytic activities of quince (Cydonia oblonga) leaf: A comparative study with green tea (Camellia sinensis). Food Chem. Toxicol. 2009, 47, 860-865. [CrossRef] [PubMed]

122. Mendes, L.; de Freitas, V.; Baptista, P.; Carvalho, M. Comparative antihemolytic and radical scavenging activities of strawberry tree (Arbutus unedo L.) leaf and fruit. Food Chem. Toxicol. 2011, 49, 2285-2291. [CrossRef] [PubMed] 
123. Fattouch, S.; Caboni, P.; Coroneo, V.; Tuberoso, C.I.G.; Angioni, A.; Dessi, S.; Marzouki, N.; Cabras, P. Antimicrobial activity of tunisian quince (Cydonia oblonga Miller) pulp and peel polyphenols extracts. J. Agric. Food Chem. 2007, 55, 963-969. [CrossRef] [PubMed]

124. Awe, E.O.; Makinde, J.M.; Adeloye, O.A.; Banjoko, S.O. Membrane stabilizing activity of Russelia equisetiformis, Schlecht \& Chan. J. Nat. Prod. 2009, 2, 3-9.

125. Besbas, S.; Mouffouk, S.; Haba, H.; Marcourt, L.; Wolfender, J.L.; Benkhaled, M. Chemical composition, antioxidant, antihemolytic and anti-inflammatory activities of Ononis mitissima L. Phytochem. Lett. 2020, 37, 63-69. [CrossRef]

126. Zhang, L.; Santos, J.S.; Cruz, T.M.; Marques, M.B.; do Carmo, M.A.V.; Azevedo, L.; Wang, Y.; Granato, D. Multivariate effects of Chinese keemun black tea grades (Camellia sinensis var. sinensis) on the phenolic composition, antioxidant, antihemolytic and cytotoxic/cytoprotection activities. Food Res. Int. 2019, 125. [CrossRef] [PubMed]

127. Escher, G.B.; Marques, M.B.; do Carmo, M.A.V.; Azevedo, L.; Furtado, M.M.; Sant'Ana, A.S.; da Silva, M.C.; Genovese, M.I.; Wen, M.; Zhang, L.; et al. Clitoria ternatea L. petal bioactive compounds display antioxidant, antihemolytic and antihypertensive effects, inhibit $\alpha$-amylase and $\alpha$-glucosidase activities and reduce human LDL cholesterol and DNA induced oxidation. Food Res. Int. 2019, 128, 108763. [CrossRef] [PubMed]

128. Jesus, F.; Gonçalves, A.C.; Alves, G.; Silva, L.R. Exploring the phenolic profile, antioxidant, antidiabetic and anti-hemolytic potential of Prunus avium vegetal parts. Food Res. Int. 2019, 116, 600-610. [CrossRef]

129. Ramchoun, M.; Sellam, K.; Harnafi, H.; Alem, C.; Benlyas, M.; Khallouki, F.; Amrani, S. Investigation of antioxidant and antihemolytic properties of Thymus satureioides collected from Tafilalet Region, south-east of Morocco. Asian Pac. J. Trop. Biomed. 2015, 5, 93-100. [CrossRef] 